\title{
Pandemic Disease, Biological Weapons, and War
}

Laura K. Donohue

Georgetown University Law Center, Ikdonohue@law.georgetown.edu

This paper can be downloaded free of charge from:

https://scholarship.law.georgetown.edu/facpub/1296

http://ssrn.com/abstract=2350304

Laura K. Donohue, Pandemic Disease, Biological Weapons, and War in LAW AND WAR: (Sarat, Austin, Douglas, Lawrence, and Umphrey, Martha Merrill, eds., Stanford University Press, 2014)

This open-access article is brought to you by the Georgetown Law Library. Posted with permission of the author. Follow this and additional works at: https://scholarship.law.georgetown.edu/facpub

Part of the Defense and Security Studies Commons, Military and Veterans Studies Commons, Military, War, and Peace Commons, and the National Security Law Commons 


\title{
Pandemic Disease, Biological Weapons, and War
}

\author{
Laura K. Donohue*
}

Over the past two decades, concern about the threat posed by biological weapons has grown. Biowarfare is not new. ${ }^{1}$ But prior to the recent trend, the threat largely centered on state use of such weapons. ${ }^{2}$ What changed with the end of the Cold War was the growing apprehension that materials and knowledge would proliferate beyond industrialized states' control, and that "rogue states" or nonstate actors would acquire and use biological weapons. ${ }^{3}$ Accordingly, in 1993 senators Samuel Nunn, Richard Lugar, and Pete Dominici expanded the Cooperative Threat Reduction Program to assist the former Soviet republics in securing biological agents and weapons knowledge. The Defense Against Weapons of Mass Destruction Act gave the Pentagon lead agency responsibility. ${ }^{4}$ Senator Lugar explained, "[B]iological weapons, materials, and know-how are now more available to terrorists and rogue nations than at any other time in our history." ${ }^{5}$ The United States was not equipped to manage the crisis. ${ }^{6}$

The actual acquisition of unconventional weapons by nonstate actors augmented concern. In 1984, for instance, the Rajneesh cult in Oregon sought to prevent the local community from being able to vote against its land development plans. ${ }^{7}$ The group contaminated local salad bars with Salmonella typhimurium, infecting 751 people. ${ }^{8}$ In 1995 Aum Shinrikyo released a sarin nerve gas attack on the Tokyo subway, killing twelve people. ${ }^{9}$ And in 1998 an American citizen, Larry Wayne Harris, obtained plague and anthrax (a vaccine strain) and isolated several other dangerous bacteria. ${ }^{10}$ His aim was to disseminate biological agents on U.S. soil, using a crop-

\footnotetext{
* Professor of Law, Georgetown Law. This document is a more recent version of Chapter 3: Pandemic Disease, Biological Weapons, and War, forthcoming in LAW AND WAR (2014).
} 
duster, to alert the U.S. government to the Iraqi biological weapons threat, and to create a separate homeland for whites. ${ }^{11}$

These and similar incidents pointed to an alarming trend: from previously a dozen or so investigations per year, in 1997, the FBI opened 74 investigations related to the possible acquisition and use of chemical, biological, radiological, or nuclear materials. ${ }^{12}$ The following year, it investigated 181 possible incidents. ${ }^{13}$ Eighty percent of the cases turned out to be hoaxes, but a significant number represented unsuccessful attacks. ${ }^{14}$ By January 31, 1999, Monterey Institute for International Studies had compiled an open-source data base of 415 such incidentsmost of which occurred toward the end of the twentieth century - where terrorists had sought to acquire or use weapons of mass destruction. ${ }^{15}$

All of this was before the attacks of September 11, 2001, and al Qaeda's stated intent to use biological weapons, backed by actual efforts to obtain biological agents. ${ }^{16}$ The anthrax attacks in autumn 2001 further underscored the threat, killing five people and infecting eighteen others. ${ }^{17}$ In 2002 President George W. Bush stated, "The gravest danger to freedom lies at the crossroads of radicalism and technology. When the spread of chemical and biological and nuclear weapons, along with ballistic missile technology—when that occurs, even weak states and small groups could attain a catastrophic power to strike great nations." ${ }^{18}$ New scholarship began focusing on the threat. ${ }^{19}$ The consensus was that it was increasingly easier and less expensive to launch a biological attack — using either natural or engineered agents. ${ }^{20}$ In order to address the challenge, domestic preparedness needed significantly more attention.

Even as the United States became increasingly concerned about terrorist acquisition or use of biological weapons, scientists and policy-makers began paying more attention to the threat posed by naturally occurring outbreaks of disease. A series of public health incidents catapulted 
the discussion forward. The first, avian influenza, emerged in Hong Kong in 1997. It infected eighteen people and killed six more. ${ }^{21}$ The disease quickly spread, becoming epizootic and panzootic, having been identified on multiple continents in eagles, tigers, domestic cats, and pigs, as well as aquatic and domesticated birds. ${ }^{22}$ Although it was not initially transferrable between humans, scientists quickly became concerned that the rapid mutations of the disease that occurred in infected animals and humans could quickly create a more virulent strain. Within a decade, the patterns of mortality had changed: whereas in 1997, most deaths occurred among patients older than thirteen years of age, by 2006 the fatality rate for infants and young children had reached 90 percent. ${ }^{23}$ Recollections of the devastation caused by the 1918 Spanish Influenza heightened fear: also avian in origin, within a year it had become one of the three worst pandemics in history. ${ }^{24}$ More than 1 billion worldwide had come down with the flu (half the world's population), with between 50 and 100 million succumbing. ${ }^{25}$ The disease had killed more than twice the number killed in World War I, with a mortality rate of only 2.5 to 5 percent. These numbers paled in comparison to the more recent strain of $\mathrm{H} 5 \mathrm{~N} 1$, where 60 percent of the humans infected with the disease had died. ${ }^{26}$ Calls for more stringent quarantine measures emerged. ${ }^{27}$

A second disease outbreak proved equally disconcerting. In 2003 severe acute respiratory syndrome (SARS), caused by a strain of the same virus underlying the common cold, hit southern China. ${ }^{28}$ Within days, it had spread from a hotel in Hong Kong to Hanoi-and as far away as Toronto. Transferred by a small number of "superspreaders," within months some eight thousand people in twenty-nine countries had contracted it, and nearly eight hundred people had died. ${ }^{29}$ The sudden proliferation of academic and policy-oriented pieces on how to fight emerging diseases followed. ${ }^{30}$ 
A third outbreak underscored not just domestic but also international concern. On June 11, 2009, the World Health Organization declared that H1N1 influenza had become pandemic, heralding the first such declaration since $1968 .^{31}$ The first cases had been identified in Mexico some two months previously. Although the pandemic proved to be less serious than first feared, ${ }^{32}$ its occurrence underscored the potentially devastating effect of the disease.

In keeping with these events, an increasing number of federal statutory and regulatory initiatives have been introduced to address the threat posed by both biological weapons and pandemic disease. ${ }^{33}$ Simultaneously, the executive branch has issued new policy documents, directing agencies to conduct better research and to make more robust preparations for responding to such threats, and laying out the planned course of action. ${ }^{34}$

Three broad observations about these initiatives follow. First, many of them tend to view biological weapons and pandemic disease through a national security lens, linking the two in terms of institutions, authorities, and approach. The Homeland Security Act of 2002, for instance, created the Department of Homeland Security (DHS), whose primary mission is to prevent terrorist attacks within the United States, reduce vulnerability of the U.S. to terrorism, and minimize damage and assist in recovery from domestic terrorist attacks ${ }^{35}$ But from the beginning, DHS saw its role as much broader. Its website declared that "[in] the event of a terrorist attack, natural disaster or other large-scale emergency, the Department of Homeland Security will assume primary responsibility ... for ensuring that emergency response professionals are prepared.” The National Response Plan underscored DHS's dual role: to assist "in the important homeland security mission of preventing terrorist attacks within the United States; reducing the vulnerability to all natural and man-made hazards; and minimizing the damage and assisting in the recovery from any type of incident that occurs. ${ }^{36}$ The Public Health 
Security and Bioterrorism Preparedness and Response Act of $2002,{ }^{37}$ as indicated by its title alone, focused on preparedness for response to public health emergencies as well as biological terrorism. The Centers for Disease Control and Prevention, in proposing broader authorities, noted, "Stopping an outbreak — whether it is naturally occurring or intentionally caused— requires the use of the most rapid and effective public health tools available. ${ }^{38}$ Homeland Security Presidential Directive 10 asserted that the traditional public health approach was no longer sufficient for the biological weapons threat: health care providers and public health officials were considered among the first lines of defense. Accordingly, a new biodefense program would combine and strengthen the state's ability to respond to biological weapons and natural disease. Similarly, in presenting the 2007 Pandemic Influenza Implementation Plan, White House officials and the Assistant Secretary of DHS underscored that the government intended to treat biological weapons and naturally occurring diseases in similar fashion: "We at DHS are focused on multi-use institutions that we can put into place for whatever emergencies arise. ${ }^{39}$ The link between the two is not just happenstance: the stated intent in releasing this document was to redefine public health as a national security priority. ${ }^{40}$

A second observation that can be drawn about the measures that have proliferated is that isolation and quarantine appear to be central to the legal framework and the policy response. ${ }^{41}$ Thus the Public Health Security and Bioterrorism Preparedness and Response Act of 2002 streamlines and clarifies communicable disease quarantine provisions. ${ }^{42}$ It makes quarantine applicable at an earlier stage by replacing language that previously required that the disease be "in a communicable stage" with a measure allowing quarantine "in a qualifying stage." 43 The White House expanded the list of quarantinable diseases to include SARS (April 2003), ${ }^{44}$ and pandemic influenza (April 2005). ${ }^{45}$ In 2003 the Department of Health and Human Services 
amended its regulations to incorporate any quarantinable diseases listed by executive order, bypassing rulemaking requirements. ${ }^{46}$ The Centers for Disease Control proposed new regulations, specifying exact periods of quarantine and the procedure to be followed in the event of its implementation. ${ }^{47} \mathrm{CDC}$ suggested that "[q]uarantine of exposed persons may be the best initial way to prevent the uncontrolled spread of highly dangerous biologic agents such as smallpox, plague, and Ebola fever.... Quarantine may be particularly important if a biologic agent has been rendered contagious, drug-resistant, or vaccine-resistant through bioengineering, making other disease control measures less effective. ${ }^{, 48}$ National exercises designed to press on response in the event of biological weapons attack include planning for mass quarantine. ${ }^{49}$ Quarantine, indeed, is at the core of the U.S. Pandemic Influenza Strategy Implementation Plan, which was issued by HHS as a blueprint for how agencies will respond in the event that avian influenza becomes human-to-human transferrable. The reason this is remarkable is that, by the document's own admission, scientists generally agree that influenza is one disease for which quarantine is likely to be particularly ineffective-yet the document refers to quarantine 138 times, and in a manner of consequence, detailing the use of quarantine both at ports of entry and in the execution of geographic quarantine (cordon sanitaire)..$^{50}$

The third observation that can be made about the measures that have been adopted is that, as biological weapons and pandemic disease have folded into the homeland defense realm, growing attention is being paid to the role of the military in enforcing such provisions. HSPD 10, for instance, considers the military to be central to U.S. biodefense. ${ }^{51}$ In large measure, this stems from the biological weapons component of the threat. But in enacting the 2002 Homeland Security Act, Congress explained that the federal government could use the military in response to any national emergency, including natural disasters. Following Hurricane Katrina, the 2007 
Defense Authorization Act made such authority explicit. ${ }^{52}$ Renaming the Insurrection Act "Enforcement of the Laws to Restore Public Order," the new language gave the president the authority to impose martial law in the event of "natural disaster, epidemic, or other serious public health emergency, terrorist attack or incident, or other condition"-without any contact or collaboration with state officials. ${ }^{53}$ The shift to federal authority immediately incurred the wrath of the state governors. ${ }^{54}$ The new powers had been "quietly tucked into the enormous defense budget bill," the New York Times pointed out, "without hearings or public debate. The president," moreover, "made no mention of the changes when he signed the measure, and neither the White House nor Congress consulted in advance with the nation's governors. ${ }^{" 55}$ Senators Patrick Leahy and Christopher Bond spearheaded new legislation that returned the Insurrection Act to its original form. Nevertheless, the incident highlighted a shift in the federal view of pandemic disease and human-engineered biological agents. Use of the military—both Title 32 troops and Title 10 forces - to respond to public health crises has broad support. ${ }^{56}$ Even without the statute, the deployment of military in Katrina was largest military deployment in domestic bounds since the Civil War. ${ }^{57}$ And the policy documents currently in place support the use of the military for medical emergencies and for help in enforcing quarantine. ${ }^{58}$

There are practical reasons for the emergence of each of the three areas identified. The association between biological weapons and pandemic disease stems from a common nexus: both involve viral or bacteriological threats to human life. Similar institutions would likely be the first to become aware of the spread of such diseases - that is, hospitals and public health entities are likely to be on the front line of defense regardless of whether the disease is natural or manmade. At the onset of disease, it may be impossible to ascertain whether a disease is naturally occurring, or the result of a concerted attack. The question thus becomes, institutionally, whether 
it even makes sense to separate them —or whether it makes more sense to have the same entities identifying and responding. The consequences of either type of threat also may be largely the same and demand that the state marshal similar resources to respond. In other words, from a mitigation perspective, it matters little whether avian flu is deliberately disseminated or happens to transfer from animals to humans. The same medical response may apply.

As for the use of quarantine and isolation, the government may be limited in the options available. For both natural diseases and for engineered weapons there may not be vaccines-or medication - available to counter the spread. Although medical opinion is divided as to the effectiveness of such measures, there does seem to be consensus about the tendency of quarantine and isolation at least to slow the spread of disease, buying time in the interim for the government and public health officials to craft a more effective response. And for those who view such steps as a last and unlikely resort, it nevertheless makes sense to think through the consequences of such measures prior to their implementation, in the event that they may be needed.

Turning to the use of the military, the armed forces have for decades been engaged in biological weapons research. The military understands many such weapons. It is likely to have a greater capacity to identify engineered diseases and potentially devastating natural diseases that have served as a basis for BW research with precision. It may have access to a broader range of antibiotics, vaccines, and prophylactic measures than civilian agencies. The military has prepared its own personnel to face such weapons in a way that civilian agencies have not. Furthermore, it may be the only institution with the necessary technology, resources, and manpower to be able to effectively counter an attack—or a pandemic disaster. 
These practical considerations are important and, indeed, have been deeply influential in the changes that are occurring. But what has become lost in the discussion are many of the constitutional questions and policy concerns that present themselves. That is, once pandemic disease and biological weapons are placed within a national security framework, disease becomes seen through a lens of war. Broader powers, with fewer checks on them, come into play. Rights become constricted, judicial remedies narrowed, and civilian agencies pushed to one side. Federalism falls even further away as a check on national authority.

Such a change may be warranted when the country is at war and civil society itself is threatened; but how does one mediate the response as a framing for all of public health, once it has been placed on a national security footing? What happens when the federal government can impose cordon sanitaire on cities, regions, or entire states, using the military to enforce it, in response to annual outbreaks of influenza?

The United States has had long experience with natural disease and its weaponization for which quarantine and isolation has been a common response. But despite the potentially devastating consequences of both threats, for much of the country's history, it was the statesnot the national government- that took the lead.

This chapter suggests that the current state of play is a result of two major shifts. The first took place during the early part of the twentieth century with the federalization of quarantine law. The second, and most recent, is the one identified above - that is, the integration of public health and biological weapons concerns, the use of quarantine and isolation for both, and the potential use of the military to enforce federal law.

While strong arguments support the first shift, the second is of concern. The history of public health law in general, and quarantine and isolation in particular, underscores four 
constitutional questions: first, the degree to which Article II claims override the tension between police powers and the Commerce Clause, driving the discussion into the realm of war; second, in looking at a growing role for the military in the realm of public health, what the contours of military deployment on U.S. soil might be; third, the extent to which Commerce Clause authorities more generally may be marshaled in the realm of public health — an area traditionally reserved to the states consistent with the Tenth Amendment; and fourth, whether recent interpretations of the Necessary and Proper Clause militate in favor of an expanded federal role in this area.

The chapter concludes its discussion with two policy considerations: whether the increasing emphasis on biological weapons risks allowing the proverbial tail to wag the dog of public health, as well as whether the use of quarantine and isolation ought to be considered as a viable response.

\section{Local Quarantine Authorities and the Weaponization of Disease}

During colonial times, disease threatened the very existence of the settlements. Land and maritime quarantine authorities were frequently introduced and rarely successful. ${ }^{59}$ They tended to be reactive and temporary, responding to reports of sickness abroad with orders forcing ships to moor offshore and preventing people or goods from entering colonial bounds. Harsh penalties for breaking quarantine applied. Massachusetts Bay, ${ }^{60}$ New York, ${ }^{61}$ the Province of

Pennsylvania, ${ }^{62}$ New-Castle upon Delaware, ${ }^{63}$ Maryland, ${ }^{64}$ Rhode Island,${ }^{65}$ South Carolina, and Virginia passed similar measures.

England strongly objected to these measures. Quarantine devastated trade. But the colonies persisted. It was well within their rights to protect colonists - indeed, the colonies 
themselves - from the threat. Special measures targeted the deliberate spread of disease, with death without benefit of clergy providing one of the strongest penalties that could be applied.

During the War of Independence, reports emerged of the English use of disease as a weapon. It was not the federal government, however, that subsequently obtained quarantine authority. Instead, following the Revolution, it was the states that subsequently incorporated quarantine provisions into their new statutes and, in some cases, their constitutions. Maryland, New York, Massachusetts, Pennsylvania, Connecticut, Delaware, South Carolina, Rhode Island, and Virginia all introduced quarantine laws, in the process conveying significant authorities to local entities. Towns were so clearly in the lead on all questions of public health, that it was left to them to decide when and to what extent communication and commerce could be severed with any other town, city, region, or state in the United States where contagion raged. Seen as the quintessential manifestation of state police powers, the protection of public health easily trumped any claims to federal Commerce Clause authority.

\section{A. Colonial Provisions}

Massachusetts Bay provides a good example of how the colonies responded to the threat of disease. In 1647 the General Court received reports that the "plague, or like grievous [in]fectious disease," had broken out in Barbados. ${ }^{66}$ The colony responded with an order instituting quarantine against all vessels arriving from the West Indies. ${ }^{67}$ No one on board would be permitted ashore, nor could anyone within the colony board such vessels, or purchase anything carried by such ships, absent a valid license. ${ }^{68}$ The penalty for violating the order was $£ 100 .{ }^{69}$ Once the yellow fever epidemic ended, the order was repealed. ${ }^{70}$ Similar response patterns marked subsequent outbreaks of disease. ${ }^{71}$ 
These measures had a significant (and negative) impact on the flow of trade, which earned England's enmity. ${ }^{72}$ The Privy Council soon became concerned that "the uncontrolled manner in which the Colony was exercising its powers was becoming increasingly detrimental to the economic welfare of England and the Empire. ${ }^{, 73}$ When Massachusetts Bay passed a particularly stringent measure in response to an outbreak of yellow fever, the Lords of Trade argued that being able to retain a ship, indefinitely, on the grounds of the presence of any contagious disease could not be allowed. ${ }^{74}$ The Privy Council agreed. "There is no such act as this," it wrote, "in any other of his Majesty's plantations." 75 The terms "contagious, epidemical and prevailing sickness" were too broad and "liable to great abuses," even as the penalties inflicted were disproportionately high. "We are therefore humbly of opinion," the Privy Council reported, "that the inconvenience thereby intended to be prevented may be better provided against by order of the Governor and Council from time to time than by any standing Act of the General Assembly." ${ }^{, 77}$ Massachusetts Bay disagreed. It immediately passed a new statute with minor alterations. ${ }^{78}$ (Instead of applying broadly to all contagious diseases, the act specified plague, smallpox, and any "pestilential or malignant fever." ${ }^{79}$

Despite a rather aggressive approach to disease, many of the provisions the colonies adopted to counter the threat proved insufficient. But instead of dispensing with such power, the colonies steadily broadened the authorities available and introduced increasingly harsh penalties. In 1714, for instance, the Massachusetts Bay General Assembly passed an act targeting vessels arriving from France and other parts of the Mediterranean. ${ }^{80}$ Any shipmaster who failed to observe the mandatory forty-day period of isolation would be put to death. ${ }^{81}$ Passengers coming ashore without express license from the governor and council would be liable to three years' imprisonment. ${ }^{82}$ 
Massachusetts Bay adopted measures enabling it to perform domestic (land) quarantine and isolation. In 1742 a statute targeting smallpox gave towns' selectmen the power to obtain a warrant to remove any persons "arriving from infected Places." ${ }^{, 83}$ For those already residing in the colony, the head of the family became required to report anyone falling ill and to mount a red flag on the "most Publick Part of the infected House." " The flag would remain there " till the House in the Judgment of the Select-Men is thoroughly aired and cleansed, upon Penalty of forfeiting and paying the Sum of fifty Pounds for each Offence, one Half for the Informer, and the other Half for the Use of the Poor of the Town where such Offence shall be committed." ${ }^{\Perp 5}$ Refusal or inability to pay the fine was punishable by whipping, up to thirty stripes. ${ }^{86}$ Where more than twenty families contracted the disease, such measures were waived. ${ }^{87}$

Several other colonies considered and adopted similarly expansive quarantine provisions. In New York, for instance, even under Dutch rule quarantine applied. ${ }^{88}$ Under English rule, the governor and council issued further orders. ${ }^{89}$ The Province of Pennsylvania also made use of quarantine. ${ }^{90}$ In 1700 the General Assembly introduced a statute prohibiting vessels arriving "from any unhealthy or sickly place" from coming closer than a mile from land, absent a clean bill of health ${ }^{91}$ Passengers and cargo could only come ashore with a permit from the local authorities. ${ }^{92}$ A $£ 100$ penalty applied.${ }^{93}$ In 1719 the General Assembly of Rhode Island and Providence Plantations at Newport passed a law to prevent any vessel carrying smallpox "or any other Contagious Disease" from anchoring within one mile of any landing place. ${ }^{94}$ The statute required license to land from the governor, or in his absence, from one or more justices of the peace, with failure to obtain such a license before landing carrying a penalty of $£ 100 .{ }^{95}$ If passengers or sailors came ashore, the justice of the peace could confine them "to any such Place, as to him shall seem convenient, for to prevent the spreading of any Infection." ${ }^{96}$ 
The threat did not just come from abroad. Colonies frequently introduced measures to prevent the spread of disease within North America. In 1721, for instance, Rhode Island passed an act requiring all goods, wares, and merchandise from Massachusetts Bay to be transferred to islands offshore, "exposed to the Sun, and Aired and Cleansed, not exceeding ten Days, nor under six days, before they shall be permitted or suffered to be brought into any Dwelling House, Shop or Warehouse in any Town within this Colony." ${ }^{97}$ Criminal penalties applied. ${ }^{98}$ The law required innkeepers to report ill lodgers and authorized justices of the peace being to remove the sick "to any such Place as they shall think needful to prevent the spreading of the same." 99

As aforementioned, many of these provisions proved unsuccessful. But instead of dispensing with such measures, the colonies often redoubled their efforts, introducing more powers and harsher penalties. Thus, as smallpox continued to plague Newport, in 1743 the colony repealed and reissued revised provisions. ${ }^{100}$ No ship, from any port, with any person ill from any contagious disease would be allowed within a mile of shore. ${ }^{101}$ The governor and justices of the peace could send medical personnel to confirm the health of the passengers. ${ }^{102}$ The Town Council controlled all communications. ${ }^{103}$ Two-thirds of the money collected from penalties incurred for breaking quarantine would be given to any informers. ${ }^{104}$ All costs associated with addressing sickness on board the vessel—including the cost of ammunition for the town's guns forced to fire at the vessel to prevent it from coming into the harbor-was to be paid for by the vessel itself. ${ }^{105}$ As for the health of the town's inhabitants, not only must inns submit health reports (with the justices of the peace empowered to remove anyone ill), but any inhabitant of the town could be forcibly removed from his or her home and placed in the local quarantine facility, "or any other convenient Place, in order to prevent the Spreading of the Infection." ${ }^{106}$ Thus emerged the legal groundwork for the use of cordon sanitaire. Guards would 
be placed to prevent anyone from entering or leaving homes or other quarantine areas, absent a town license. ${ }^{107} \mathrm{~A}$ fine accompanied any infractions, with half to be paid to any informers. ${ }^{108}$

The harshest penalties applied to knowing dissemination of disease. The law made it a crime to willfully or purposely spread smallpox within the colony. ${ }^{109}$ Anyone found guilty of doing so would be put to death "without Benefit of the Clergy." 110 The attempt to spread disease earned a similarly stringent punishment: all individuals "legally convicted of wickedly endeavouring to spread [smallpox], shall be sentenced to be whipped, not exceeding Thirty Nine Lashes, and suffer Six Months Imprisonment, and be kept to hard Labour."111

B. The War of Independence

During the Revolutionary War, more than 130,000 colonists died from smallpox-an outbreak attributed at the time to British use of the disease as a weapon. ${ }^{112}$ Reports first surfaced that the British were engaged in biological warfare during the siege of Boston. By 1781 further reports emerged of the deliberate spread of smallpox in Virginia. ${ }^{113}$ Other accounts followed: the Pennsylvania Gazette, for instance, wrote, "Lord Cornwallis's attempt to spread the smallpox among the inhabitants in the vicinity of York, as been reduced to a certainty, and must render him contemptible in the eyes of every civilized nation." ${ }^{114}$ Benjamin Franklin noted as much in his Retort Curteous. ${ }^{115}$ Historian Elizabeth Anne Fenn writes, "It would be easy to dismiss these accusations as so much American hyperbole. But evidence indicates that in fact, the British did exactly what the Americans said they did."

The disease had a significant impact on the colonists' effort to win independence. It decimated the Revolutionary Army at a critical time. ${ }^{117}$ The colonies, however, responded not by introducing broader authorities or more stringent penalties, but by taking advantage of what little was known, scientifically, about the disease. In Massachusetts, for instance, new laws authorized 
justices of the court of general sessions in any county to establish inoculating hospitals. ${ }^{118}$ In Rhode-Island and elsewhere, similar measures permitted widespread inoculation. ${ }^{119}$

Following the Revolution, despite the use of smallpox as a weapon, and the devastating impact of the disease, the states — not the federal government — continued to take the lead. Maryland, for example, which introduced quarantine regulations in 1766, continued the act in $1769,1773,1777,1784,1785,1792$, and $1799 .{ }^{120}$ Upon reaching statehood, Maryland transferred quarantine authorities to its constitution. Article 33 empowers the governor to "order and compel any vessel to ride quarantine, if such vessel, or the port from which she shall have come, shall, on strong grounds, be suspected to be infected with the plague." ${ }^{\prime 21}$ The governor's authority to quarantine appears in the same sentence as the governor's power, with the advice and consent of the council, to embody and direct the state militia, suggesting a close correlation between these authorities as an aspect of state sovereignty as well as state defense. ${ }^{122}$ Concerned that even these provisions were insufficient, subsequent legislation expanded the governor's authority. From 1793 the governor's powers in regard to any malignant contagious disease, included the authority not just to prevent ships, goods, or persons from stepping on shore, but to prevent "all intercourse or communication," over land or water, between Maryland and any region where such sickness was present—-both in the United States and abroad. ${ }^{123}$ The governor thus had the authority to sever domestic relations. Quarantine was so decidedly local, that it overrode the union.

The context mattered: the union initially was not strong, as the failure of the Articles of Confederation was to attest. State measures provided the first and last line of defense. But even decades after the adoption of the U.S. Constitution, states continued to emphasize the autonomy of not just state but also local authorities in the exercise of quarantine and response to disease. 
Maryland, for instance, made arrangements for the appointment of a local health officer in Baltimore, who had the independent authority to authorize the quarantine of people and goods for up to thirty days. ${ }^{124}$ Local ordinances continued this trend, with Baltimore passing measures in 1797,1798 , and 1800 , making further provisions for quarantine and the establishment of a lazaretto to perfect the same. ${ }^{125}$

New York, Massachusetts, Pennsylvania, Delaware, Connecticut, Delaware, South Carolina, Rhode Island, and Virginia followed a similar pattern. ${ }^{126}$ Authorities extended well beyond maritime quarantine. In 1797, for instance, Massachusetts empowered selectmen to remove and isolate any sick persons found within the town boundaries. ${ }^{127}$ Broad humanitarian contours applied: isolation must be given effect in the "best way ... for the preservation of the inhabitants, by removing such sick or infected person or persons, and placing him or them in a separate house or houses, and by providing nurses, attendance, and other assistance and necessaries for them. ${ }^{, 128}$ Like Maryland, Massachusetts drew a line between the state and the rest of the country. Towns could require that anyone arriving from a region in the United States in which contagious disease could be found to notify town authorities within two hours of their arrival. ${ }^{129}$ Justices of the peace then had the authority to force any visitors to leave, with up to a $\$ 400$ fine for lack of cooperation. ${ }^{130}$ Any inhabitant of the town entertaining a visitor for more than two hours after the departure warrant had been issued could be fined. ${ }^{131}$ Similar authorities, pari passu, were given to local authorities to prevent any baggage or goods originating outside the state from entering town boundaries. ${ }^{132}$

It was not just quarantine law that fell within local power. Broad public health concerns lay, too, within their reach. Massachusetts soon established a Board of Health in Boston, which focused on 
[all] such sources of filth as may be injurious to the health of the inhabitants of said town, whether the same shall proceed from stagnant waters, cellars, drains, common sewers, slaughter-houses, tan-yards, fish, fish-houses, fishing-boats, fish-boxes, oysters, oysterboats, hogs, hog-sties, docks, necessaries, livery and other stables, putrid animal and vegetable substances, vessels, scows, or boats, or any other cause of any nature or kind whatsoever, which, in their opinion, may be injurious to the health of the inhabitants . . 133

Board members could make forcible entry to carry out their duties. ${ }^{134}$ To this board also were assigned additional quarantine authorities, within which it had broad leeway. ${ }^{135}$

Some states went further. In 1794, for example, Connecticut introduced a statute allowing towns to exile any sick person carrying a contagious sickness, where such infection "may probably be communicated to others. ${ }^{, 136}$ In the event that a suitable nurse could not be found, a warrant could be issued to other towns in Connecticut, requiring them to provide assistance. ${ }^{137} \mathrm{~A}$ heavy fine attached. Where individuals became sick, with any infectious disease, the head of the family became required to fly a white flag, which could be removed only by the selectmen or by a justice of the peace. ${ }^{138}$ In the event that contagious disease struck a town, all dog owners became required to "destroy their Dogs or cause them to be killed." 139 Anyone infecting any town in Connecticut, either by land or water, incurred a fine, with the selectmen ascertaining the length and manner of airing of all commercial goods. ${ }^{140}$ Connecticut criminalized the transfer of smallpox, with the burden of proof shifted to the person thus accused. ${ }^{141}$

\section{Federal Reticence}

Throughout this time, public health was firmly in the hands of the states, which, in turn, delegated the authority to local entities to determine when and how to give effect to the 
provisions. ${ }^{142}$ The national government proved reluctant to become involved. Its initial response was to duck and run: the first federal statute on the topic simply allowed Congress to reconvene outside the capitol where "the prevalence of contagious sickness" or "other circumstances ... hazardous to the lives or health of the members" should occur. ${ }^{143}$ It was not until two decades after the Revolution that Congress directly addressed quarantine, at which time it passed a measure subordinating the national government to the states. ${ }^{144}$ Repealed three years later, the statute allowed the president to provide assistance in enforcing quarantine, if states first requested it. ${ }^{145}$

Debates in Congress preceding enactment of the measure demonstrated uneasiness at curbing state rights and giving too much power to the federal government. ${ }^{146}$ The original bill would have given the executive branch the authority to determine where quarantine stations would be located. The House of Representatives strongly objected. Quarantine lay within the states' purview. ${ }^{147}$ Its impact on commerce paled in comparison to the importance of quarantine in maintaining public health, which lay at the heart of state police power. ${ }^{148}$

Beyond the principled objections lay practical constraints. States were on the front line of defense, and communication with the national government took too much time. ${ }^{149}$ It was for this reason that states had long been "in the habit of regulating quarantine, without consulting the General Government. ${ }^{, 150}$ Life and death depended on speed. ${ }^{151}$ And history proved important: states had previously introduced such measures—quod erat demonstrandum, quarantine must be a state power. ${ }^{152}$ The few who supported a stronger federal role heavily relied on the Commerce Clause in their assertions. ${ }^{153}$ They argued that as a practical matter, moreover, the federal government had the authority—and resources— to ensure compliance. ${ }^{154}$ But their pleas fell on deaf ears, and the bill passed, absent the offensive language. 
The federal government thus embarked on a path that subordinated it to state interests. Resultantly, when Congress created the first marine hospital in 1796, the institution was left in local control. ${ }^{155}$ Three years later Congress repealed the act, giving Treasury the authority to require that U.S. officers assist in executing quarantine laws, consistent with state health provisions. ${ }^{156}$ (In recognition of constitutional limitations, the statute explicitly noted that alterations to duties of tonnage would require further congressional approval.) ${ }^{157}$ With the federal government in a supportive role, the debates preceding adoption of the bill did not center on state rights. $^{158}$

Nevertheless, the statute marked the first forays of the federal government into the quarantine domain, by creating a federal inspection system for maritime quarantine. ${ }^{159}$ Under Treasury's auspices, the national government could now obtain information about the spread of disease along the Eastern seaboard. ${ }^{160}$ Subsequent orders issued by the Secretary of the Treasury reiterated that Marine Hospital Service Officers, customs officials, and revenue officers were to cooperate in enforcing local quarantine law and regulations. ${ }^{161}$

By the nineteenth century, public health generally, and quarantine in particular, had become firmly established as within the state domain. Accordingly, in Gibbons v. Ogden, Chief Justice Marshall described state police powers as:

That immense mass of legislation, which embraces every thing within the territory of a State, not surrendered to the general government: all which can be most advantageously exercised by the States themselves. Inspection laws, quarantine laws, health laws of every description, as well as laws for regulating the internal commerce of a State . . ${ }^{162}$ Marshall's articulation summarized the state of play and became its own source of authority. The attorney general subsequently relied on Gibbons to explain to the Secretary of the Treasury why 
the federal government could not itself issue quarantine regulations. ${ }^{163}$ State courts concurred. ${ }^{164}$ The states steadily expanded their reach into the public health arena, establishing local boards of health and delegating to them when, where, and in what manner quarantine would be given effect. $^{165}$

\section{Establishing the Federal Domain}

While public health and quarantine remained central to state interests, the commercial impact of a localized quarantine system gradually attracted more attention. ${ }^{166}$ Debates between contagionists and noncontagionists further underscored the importance of a federal solution. The Confederate Army harnessed disease as a weapon during the Civil War. Nevertheless, federal controls did not immediately follow. The formation of the Marine Hospital Service, and its more effective use of quarantine, however, again focused attention on a federal solution. Encouraged by judicial opinions, Congress began to legislate in this area. But progress was gradual. By the early twentieth century, the federal government had yet to preempt the states, which continued to exercise their authorities. Ultimately, a direct confrontation between state police powers and potential Commerce Clause claims was avoided through congressional leverage of the Spending Clause. Treasury bought up the ports, thus the authority to exercise maritime quarantine. These authorities eventually extended into the interior as the Public Health Act, and, later, the Stafford Act provided federal authority to impose quarantine.

\section{A. Foreign Relations}

European powers, all of whom had long experience with quarantine as a way to stem the introduction of disease, considered the localized American system to be outdated and ineffective. Ships arriving in the United States from Central and South America, prior to making the voyage 
across the Atlantic, were not subjected to particularly rigorous inspection; nor did the United States require bills of health or other assurances from ships departing from U.S. shores. The new country's vessels thus soon found themselves subject to stringent measures, requiring American vessels, upon arriving in Europe, to remain in quarantine longer than those of other countries. Efforts to convince Spain, England, and others to change these provisions fell on deaf ears. Foreign countries simply did not trust vessels coming from the United States. ${ }^{167}$

Part of the problem with the U.S. approach was, precisely, the localized nature of quarantine. The manner in which inspections and quarantine operated varied between ports. Significantly different rules, standards, and levels of compliance existed.

Two problems thus presented themselves: the first centered on U.S. foreign relations and the impact the localized system was having on U.S. trade abroad. The second stemmed from the domestic arena, as the uneven application of public health measures created friction within the United States as well. ${ }^{168}$ Congress began to lament the system as provincial and unscientific. ${ }^{169}$ Considering the magic influence of names, it were to be wished that the term quarantine should be erased from the statute books of the Union, and of each particular State.

Regulations, precise and explicit, should, in the opinion of your committee, be formed to prevent foul and infectious vessels, with sickly crews, from entering our ports, or proceeding on any voyage in that situation. ${ }^{170}$

A uniform federal system would help to ensure stronger sanitary provisions and alleviate European concern about vessels arriving from the United States. ${ }^{171}$

Two civil reform groups leant momentum to the political interest in federal control. Contagionists, believing that disease transferred by individuals coming into contact with each other, sought a more stringent and uniform system. ${ }^{172}$ Anticontagionists advocated for better 
national sanitation and an end to the local (indeed, any) quarantine regime. ${ }^{173}$ Either way, a federal solution, predicated on the Commerce Clause, provided the answer. The Committee on External Hygiene explained:

We consider that quarantine from its close connection with the U.S. Revenue Department, and the important bearing which it has upon commerce (which Congress alone can regulate) and upon travellers soon to be disperse throughout different and distant States of the Union, is a national, rather than a State concern, and we cannot conceive that a uniform system of quarantine can be established throughout the Union unless it be organized ... as a national institution. ${ }^{174}$

A series of National Quarantine and Sanitary conventions focused on not if, but how to reform the system and to transfer control to the federal government. ${ }^{175}$ Such meetings ceased as the country fell into the Civil War.

As during the Revolutionary War, disease became a weapon. Scholars report that the Confederacy tried to spread yellow fever, smallpox, and other diseases among Union soldiers and civilians. ${ }^{176}$ Plans ranged from sending infected individuals behind enemy lines and distributing goods carrying contagion, to contaminating water sources. ${ }^{177}$ In 1863 this method of warfare prompted the Union to issue an order outlawing the use of such techniques. ${ }^{178}$

Natural outbreaks of disease during the war further illustrated the degree to which states depended on other regions to prevent the transfer of disease. ${ }^{179}$ But state rights still trumped. In 1865 the administration brought forward a bill to give the Secretary of War, with the assistance of the secretaries of the Navy and Treasury, the authority to enforce quarantine at all ports of entry, as well as domestic cordon sanitaire. ${ }^{180}$ Senators were incredulous. Henry B. Anthony (RRI) questioned the chair of the Commerce Committee on the extent of the proposed authorities. 
"[All] the powers at their command may be used if necessary," Senator Zachariah Chandler replied. ${ }^{181}$ Shocked, Anthony inquired whether the Secretary of War could impose martial law to stem the tide of disease. Chandler answered that they could "use any power requisite to stop the cholera." Anthony objected: "I would rather have the cholera than such a proposition as this." 182 Historian Les Benedict explains, "Although during the Civil War a growing number of people were demanding vigorous exercise of national authority, most Americans still regarded general police regulation - the ordinary day-to-day legislation affecting crime, health, sanitation, personal property, etc.- - to be the responsibility primarily of the states." ${ }^{\text {183 }}$ Many congressional members considered state and national quarantine authority, as in interstate commerce, to be mutually exclusive. ${ }^{184}$ Lot M. Morrill (R-ME), maintained, "All sanitary regulations touching the health of this country within the jurisdictional limits of the several States are matters of police regulations." ${ }^{.185}$ While the Civil War thus may have marked an important step in the evolution of American federalism, it was not immediately reflected in the realm of public health. By the late nineteenth century, however, things started to change.

\section{B. Economic Considerations and the Commerce Clause}

Federal initiatives remained highly sensitive to state concerns. The move toward greater federal involvement, when it did come, was not one grounded in war or national security, but rather economic concerns: namely, the impact of disease on trade and the costs of maintaining a robust system. Institutional reforms, which allowed the federal government to have greater insight into the introduction and transfer of disease, and scientific advances, which moved quarantine to a rational-based system, here mattered. ${ }^{186}$

In 1878 Congress introduced a new quarantine act. ${ }^{187}$ The statute marked the federal government's first assertion of control over quarantine, yet important limits applied. Regulations 
could govern only the arrival of ships from foreign ports. ${ }^{188}$ They could not run afoul of state or municipal authorities. ${ }^{189}$ The statute also created a worldwide surveillance system, requiring U.S. officers based overseas to send weekly reports on the health of foreign ports and to inform the supervising surgeon general of the outbreak of any contagious diseases abroad. ${ }^{190}$ Congress made further provision for underwriting scientific research on "the origin and causes of epidemic diseases, especially yellow fever and cholera, and the best method of preventing their introduction and spread." 191

The following year Congress expanded the number of federal quarantine stations and created a national board of health. ${ }^{192}$ Again, restrictions emphasized the primacy of the states. Members of the national board were directed to cooperate with and to help the local and state boards of health, with their responsibilities limited to matters concerning cholera, smallpox, and yellow fever. This time, however, Congress considerably loosened the purse strings, which was to prove critical in the transfer of authorities to the federal government. The statute allowed Treasury to buy up local ports, in the process assuming responsibility for stopping disease at the borders. Local entities could voluntarily relinquish their authority, in return for financial remuneration and preventing further drains on state coffers. Three years later, Congress freed up money for states to request (and receive) up to $\$ 100,000$ to assist in the event of an actual or threatened epidemic. ${ }^{193}$

Even as early success stories involving the Marine Hospital Service lent momentum to a new federal role ${ }^{194}$ frustration about the current system grew. State measures were reactive and failed to take into account broader public health needs. ${ }^{195}$ The federal government had to wait until states requested assistance—-which meant that it was not until epidemics were underway that they could act. ${ }^{196}$ Local health laws, focused on local interests, had become corrupted by 
"the commercial interests of rival ports, the partisan struggles of opposing political factions, and the heedless parsimony with which money has been doled out." ${ }^{197}$ Ports of entry lacked incentives to protect inland areas. ${ }^{198}$ Sanitary measures fell short: placing immigrants arriving with a multitude of sicknesses in crowded, poorly ventilated, and unsanitary quarters, and then sending them throughout the United States begged credulity. ${ }^{199}$

Proponents of a stronger federal role argued that it would, in contrast, create a uniform approach and ensure that the costs were shared. The result would be better training for immigration officers and, by stopping disease at the borders, the alleviation of barriers to interstate trade. The federal government could shift its resources to ports in need, avoiding the quagmire of local politics. ${ }^{200} \mathrm{~A}$ consensus among leaders in medicine, industry, and politics slowly emerged: the federal government needed to be in charge. ${ }^{201}$

A timely case spurred the courts to consider the contours of state and federal authority. At issue in Morgan's Steamship v. Louisiana Board of Health was the right of the state legislators to require vessels entering the Mississippi River to be examined and to pay a fee for the inspection. ${ }^{202}$ The shipping company challenged the statute on the grounds that the measures imposed tonnage duties and interfered with the federal regulation of commerce. ${ }^{203}$ The Supreme Court rejected this argument, saying that the precautions taken by the state were "part of and inherent in every system of quarantine.” Despite the impact of quarantine on commerce, such matters were reserved to the states—at least until invalidated by Congress:

[It] may be conceded that whenever Congress shall undertake to provide for the commercial cities of the United States a general system of quarantine, or shall confide the execution of the details of such a system to a National Board of Health, or to local boards, as may be found expedient, all State laws on this subject will be abrogated, at 
least so far as the two are inconsistent. But until this is done, the laws of the State on this subject are valid. ${ }^{204}$

No longer, then, as Marshall had articulated in 1824, did public health and quarantine lie solely within the state domain, but now the federal government could potentially act in this arena. Congress readily accepted the invitation.

Over the next five years, federal initiatives followed on nearly an annual basis. ${ }^{205} \mathrm{~A}$ relatively important change came in 1890 , when Congress gave permission to Treasury to issue regulations to prevent the interstate spread of cholera, yellow-fever, smallpox, and plague. ${ }^{206}$ The statute carried criminal penalties. It became a misdemeanor for any U.S. officer or agent to violate federal quarantine laws. ${ }^{207}$ Common carriers warranted stronger punishment for violations. ${ }^{208}$

Another important change came in 1893, when Congress repealed the 1879 legislation. ${ }^{209}$ The statute required the supervising surgeon-general to conduct a study of all state and municipal boards of health and to help both the states and the federal government enforce the rules in force. It also gave Treasury the authority to enact further regulations where state and municipal ordinances did not exist or were inadequate. State and local officers would enforce federal regulations voluntarily; absent such cooperation, the federal government would enforce them itself. ${ }^{210}$ Treasury could purchase warehouses to hold goods subject to quarantine under either state or federal regulations, with the secretary authorized to prolong the period of retention (at Treasury's expense), subject to state law. ${ }^{211}$ The legislation required that all vessels entering U.S. waters from foreign ports first obtain a bill of health from U.S. officers overseas. When infected vessels arrived, Treasury could remand the vessel, at its own expense, to the nearest quarantine station. ${ }^{212}$ To the president was given the authority to prohibit the introduction of individuals or 
goods from any designated region in which contagious disease was prevalent. ${ }^{213}$ Treasury could receive any state buildings and disinfecting equipment, and pay reasonable compensation for the same, where considered necessary to defend the U.S. against disease. ${ }^{214}$

The judiciary continued to hold the line drawn in Morgan's Steamship. In 1902, Justice White explained that states had the power to enact and enforce laws to prevent, eradicate, and control the spread of contagious or infectious diseases. ${ }^{215}$ Such authority could be preempted. W] henever Congress shall undertake to provide ... a general system of quarantine, or shall confide the execution of the details of such a system to a national board of health, or to local boards, as may be found expedient, all state laws on the subject will be abrogated, at least so far as the two are inconsistent. ${ }^{216}$

But until the legislature acted, "such state quarantine laws and state laws for the purpose of preventing, eradicating or controlling the spread of contagious or infectious diseases, are not repugnant to the constitution." ${ }^{217}$ Three years later, Justice Marshall Harlan reiterated, "Upon the principle of self-defense, of paramount necessity, a community has the right to protect itself against an epidemic of disease which threatens the safety of its members. ${ }^{218}$ Like quarantine, the compulsory smallpox vaccination at issue in Jacobson v. Massachusetts was a legitimate exercise of state police power to protect public health. ${ }^{219}$

States continued to consider public health as central to state police powers. ${ }^{220}$ In 1913, however, another incremental shift militated in favor of federal power. The Supreme Court responded to the Minnesota Rate Cases by suggesting that states were free to adopt only quarantine regulations that did not conflict with federal statutory or regulatory initiatives: "In view of the need of conforming such measures to local conditions, Congress from the beginning has been content to leave the matter for the most part, notwithstanding its vast importance, to the 
States and has repeatedly acquiesced in the enforcement of State laws." ${ }^{, 21}$ The subtle undertones of the decision suggested not that the states had the ultimate authority, but that it was only by leave of Congress that they could act in this area.

Throughout this time, federal agencies quietly continued to assist the states and to accept the responsibility of running the quarantine system in what one mid-twentieth-century scholar referred to as "a process of accretion and erosion.",222 In 1921 the last state (New York) transferred its quarantine facilities. ${ }^{223}$ The federal government at that point controlled roughly 100 stations and inspected some 2 million passengers and crew and 20,000 vessels per year. ${ }^{224}$ Surgeon General Hugh Cumming noted:

The transition of a quarantine system, composed of units operated by the municipal or state authorities, to a compact federal organization has been gradual, but persistent. One after another cities and states have transferred their quarantine stations to the national Government, so that, with the passing of the New York Quarantine Station from state to national control on March 1, 1921, the Public Health Service now administers every station in the United States and in the Hawaiian Islands, the Philippines, Porto Rico, and the Virgin Islands. ${ }^{225}$

Cumming proclaimed it the triumph of science over politics.

\section{Current Federal Authorities}

Within about two decades of the federal government assuming control of the ports, Congress passed measures giving the executive branch the authority to place individuals and goods in quarantine. This legislation, the 1944 Public Health Service Act, ${ }^{226}$ is one of two pillars on which the current federal system rests. The second is the 1988 Robert T. Stafford Disaster Relief and Emergency Assistance Act. ${ }^{227}$ 
Under the former, the Secretary of Health and Human Services (HHS) has the authority to make and enforce regulations necessary "to prevent the introduction, transmission, spread of communicable diseases from foreign countries into the states or possessions, or from one State or possession into any other State or possession. ${ }^{, 228}$ Quarantine can be exercised only for diseases listed in Executive Order 13295. Since 1983, cholera, diphtheria, infectious tuberculosis, plague, smallpox, yellow fever, and viral hemorrhagic fevers have been included. In April 2003 President Bush added SARS, and the following year, pandemic influenza. ${ }^{229}$

The Secretary of HHS may apprehend and examine any individual reasonably believed to be infected with a designated disease in a qualifying stage and (1) moving or being about to move between states, or (2) a probable source of infection to individuals who may be moving between states. ${ }^{230}$ Where infection is found, HHS can detain the individual for such a time, and in such as manner as may be reasonably necessary. ${ }^{231}$ Current regulations prohibit infected individuals from traveling across state lines without explicit approval from a health officer of the destination region, if applicable under their law. ${ }^{232} \mathrm{CDC}$ maintains control over individuals arriving from foreign countries, while the surgeon general has the power to prohibit designated persons or goods from entering the United States altogether. ${ }^{233}$

The above regulations focus on regular authorities during peacetime. In times of war, special powers apply. The Secretary of HHS, in consultation with the surgeon general, may indefinitely detain individuals reasonably believed to be infected, and a probable source of infection to members of the armed forces of the United States or to individuals engaged in the production or transportation of supplies to the armed forces. ${ }^{234}$ Unlike peacetime authorities, it is not necessary for an individual to be in a qualifying stage of infection. Eligible diseases continue to be limited by Executive Order 13295. 
The surgeon general controls all quarantine stations and may establish whatever new stations may be considered necessary. ${ }^{235}$ Overseas consulates are required to report on diseases abroad, consistent with rules set forth by the surgeon general. ${ }^{236}$ Bills of health continue to be required for all vessels entering or leaving U.S. water and air space. ${ }^{237}$ Violation of general federal quarantine provisions is punishable as a criminal misdemeanor, with the violations of specific orders subject to a fine of up to $\$ 250,000$, or one year in jail, or both. ${ }^{238}$ Federal District Courts may enjoin individuals and organizations from violating CDC regulations. ${ }^{239}$

The second piece of legislation marking the framework is the Robert T. Stafford Disaster Relief and Emergency Assistance Act. ${ }^{240}$ This legislation is the legacy of the eighteenth-century measures designed to allow the federal government to respond to requests for assistance in the event of an emergency. In 2000 the Disaster Mitigation Act amended the Stafford Act to encourage state, local, and tribal areas to coordinate planning prior to actual disasters. ${ }^{241}$

Two types of declaration may be made under the Stafford Act: a major disaster declaration consistent with Title IV, and an emergency declaration under Title V. The former depends upon a state governor making a formal request to the president for federal assistance. Such help can apply only to natural catastrophes, or, regardless of their source, actual fires, floods, or explosions. The language, then, does not appear to include non-natural incidents, such as criminal activity, terrorist attacks, or acts of war (although it would include any fires, floods, or explosions thereby resulting). In order to qualify for assistance, states must have previously implemented a plan in coordination with the federal government. The president has the option of declining the request. ${ }^{242}$ While the statute does not explicitly mention quarantine, it does give the executive the ability to provide health and safety measures (presumably included the detention of 
those suspected of carrying contagious disease). ${ }^{243}$ There is no limit on the amount of funds that can be requested.

Under Title $\mathrm{V}$, an emergency declaration may be made either pursuant to the request of a governor, or the president may simply declare an emergency in which the incident involves an area of "primary Federal responsibility." For the former, the decision to grant the request is discretionary. There are no limits on the type of emergency for which help is requested, but the total amount that can be obtained is limited to $\$ 5$ million per declaration. ${ }^{244}$ For the latter, it is not entirely clear what constitutes an area of primary responsibility. Rather, the statute provides a general category - that is, "subject area[s] for which, under the Constitution or laws of the United States, the United States exercises exclusive or preeminent responsibility and authority. ${ }^{, 245}$ In practice, unilateral declarations have tended to involve federal property. In such cases, FEMA has primary responsibility (arguably bypassing the Secretary of DHS altogether).

Quarantine measures continue to be in flux. In 2005 the Centers for Disease Control proposed new regulations that would structure quarantine along the incubation period of each disease, as well as allow for administrative review. ${ }^{246}$ Largely in response to concerns expressed by common carriers, which would have been required to collect more information from their customers as part of the rule change, the initiative was stalled. More recently, the Department of Health and Human Services updated five existing definitions, added thirteen new definitions, and created a new scope and definitions section in the existing law. ${ }^{247}$

As noted at the beginning of this chapter, these regulations are but one part of a much broader movement to address both biological weapons and pandemic disease. The Department of Health and Human Services, the Centers for Disease Control, the Department of Homeland 
Security, and the Department of Defense, among other agencies and departments, have taken steps to respond more effectively to the twin threats.

Three observations about the recent measures follow: first, they tend to link biological weapons and naturally occurring disease, seeing both as a national security threat; second, they emphasize quarantine and isolation as a potential response; and third, they anticipate the use of the military to enforce social distancing provisions. As outlined in the above sections, the recent changes represent a second major shift that has occurred in the United States in the realm of public health and quarantine law.

\section{Constitutional and Policy Challenges Going Forward}

In the early twentieth century the move to federal control over the introduction of disease and its transfer between the states marked an uneasy detente between the powers reserved to the states through the Tenth Amendment and Commerce Clause authorities. Practical economic concerns and the Spending Clause proved critical in carving out a federal role. The most recent shift, however, raises a number of further constitutional concerns not as easily accommodated within the U.S. legal tradition.

Some portion of these concerns center on individual rights. Scholars have considered many of the potential rights violations embedded in broader quarantine authorities, such as Fifth Amendment due process and the writ of habeas corpus under the Suspension Clause. ${ }^{248}$ These are important concerns. Notably, the courts have yet to address many of the most important questions in this realm, such as how long an individual may be held in quarantine or isolation before a hearing is required, precisely what procedures may satisfy due process, or what evidence must be produced to justify restrictions on liberty. Nor have courts considered the level 
of direction that must be given, and the degree of noncompliance required, to justify forcible detention. ${ }^{249}$ Some challenges have been raised on takings grounds; here, too, the record is fairly sparse. $^{250}$

But beyond these concerns, almost no attention has been paid to the structural issues that present themselves: specifically, the articulation of public health as an Article II claim, the role of the military in executing quarantine and isolation on domestic soil, the limits of federal Commerce Clause authorities in light of Tenth Amendment state police powers, and evolution of Necessary and Proper Clause jurisprudence.

Additionally, at least two important policy considerations attend: the extent to which biological weapons concerns may achieve preeminence and thus drive the subsequent public health discussion; and whether quarantine and isolation should be looked to as a first response. While it is not the intent of this chapter to conclusively explore these concerns, each deserves some attention.

\section{A. Public Health as Article II War Powers}

The first and perhaps most important structural question that presents itself relates to the shift in collapsing pandemic disease and biological weapons into a national security framework. Consider the most recent U.S. National Security Strategy, issued in May 2010, which cites, inter alia, weapons of mass destruction, pandemic disease, natural disasters, and terrorism as pressing national security concerns. ${ }^{251}$ Coupled with a new role for the Department of Defense, the specter of treating public health concerns within a war, or national security emergency framing, presents itself. The result bypasses the uneasy accommodation between state police powers and Commerce Clause considerations, pushing the constitutional analysis into an Article II realm. 
The Constitution divides war powers between the executive and legislative branches. In Article II, it falls to the president to execute the powers of commander-in-chief. ${ }^{252}$ Under Article I, Congress is imbued with the authority to declare war and to appropriate U.S. treasure for the same. ${ }^{253}$ To the legislature also is given the authority to call forth the militia, suppress insurrections, and repel invasions. ${ }^{254}$ Between these, a sort of "twilight zone" of concurrent authorities operates. ${ }^{255}$ As Justice Jackson famously suggested in Youngstown, where the president acts with congressional authorization, his authority within this area of concurrent power is at its zenith. ${ }^{256}$

Where statutory measures, such as the changes to the 2007 Defense Authorization Act, explicitly award the president the authority to use the military to respond to natural disasters, pandemic disease, or terrorist attack, the president appears to be acting in full power.

But Congress did not end its treatment of the federal role in regard to quarantine with the passage of the 2007 statute. Instead, in response to strong opposition from state governors, Congress subsequently withdrew the relevant provisions. Resultantly, in the event of pandemic disease, at least as a matter of the president's commander-in-chief authorities, a strong argument could be marshaled that the president would be acting neither in the zone of explicit congressional approval, nor absence of the same, but at the "lowest ebb": that is, where Congress has explicitly withdrawn such authority. Admittedly, withdrawing a power is not the same as affirmatively denying its existence. At a minimum, however, the explicit withdrawal of congressional consent suggests a lower threshold than that of legislative sanction.

So the framing of pandemic disease as a national security concern-particularly where the initial outbreak of disease may or may not have arisen from a biological weapons attackgives rise to the question of where the president's defensive power ends and Congress's authority 
over the decision to take the nation to war begins. As a textual matter, Congress has the power to initiate a condition of war. The president does not. Conversely, the president has the power to conduct war. Congress does not. The careful selection of the word "declare," rather than "make" appears to have been designed to retain in the president the traditional authority to defend the nation against, or "repel," sudden or imminent attacks - that is, a defensive war power. It also appears to sidestep any suggestion that Congress's power to declare war also carries the authority to manage the conduct of the war.

So what happens if the president responds to an outbreak of disease as an act of war, on the grounds that such events may (or may not) stem from biological attack? Does the president have the authority to do so?

Consider the question of mobilization - that is, the decision to employ the country's armed forces to respond to a potential pandemic (or biological weapons attack). For much of the modern period, executive practice with regard to the commitment of troops and use of the military has substantially departed from the constitutional text. The Korean War (1950-53), the Cuban missile crisis, Kosovo (1999), the recent bombing of Libya (2011), and a broad range of covert operations (such as the invasion of Grenada [1983]) have involved substantial military commitments that occurred outside explicit congressional approval or declaration of war. If an epidemic or outbreak of disease were to be classed as an act of war, in what sort of capacity could the military be used and for what duration?

The 1973 War Powers Resolution, passed in response to perceived overexpansion of

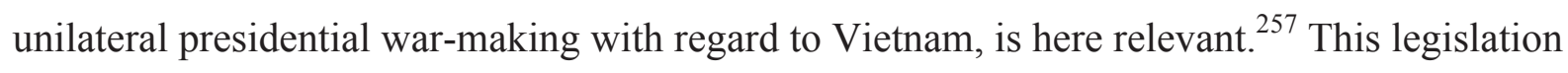
authorizes the president to use military force in three circumstances: declaration of war, specific statutory authorization, or national emergency. ${ }^{258}$ The president must consult Congress in every 
possible instance. Any military action must be reported within forty-eight hours, and use of the forces must terminate within sixty days of a report to Congress, unless war is declared, a sixtyday extension is granted by Congress, or Congress is physically unable to meet. There is a sense in which this statute, coupled with a failure to terminate presidential military action, has implicitly created a sixty-day "safe harbor" for unilateral presidential action.

Successive administrations, beginning with Nixon, have questioned the constitutionality of the War Powers Resolution. ${ }^{259}$ They have argued that it is an unconstitutional usurpation of Article II authority, undermines US foreign policy, fails to require positive congressional action, and undermines executive and legislative branch cooperation. ${ }^{260}$

These arguments can be challenged. As a textual matter, it falls to Congress, not the president, to move the country to a state of war. If one grants the constitutionality of the resolution, then the statute may apply to situations in which the president seeks to use the military in response to a perceived pandemic or biological weapons attack. The limits, however, laid out in the statute would apply.

Notably, the debates over the War Powers Resolution, have been predicated largely on the president's use of the military overseas. ${ }^{261}$ What happens when the question becomes the use of the military on domestic soil? Constitutional jurisprudence here is particularly thin.

In 1862 the Prize Cases were argued before the Supreme Court, which considered the constitutionality of President Lincoln's blockade of Southern ports. ${ }^{262}$ Justice Robert Grier, writing for the Court, suggested that the president, as commander-in-chief of the armed forces, had a broad range of power, including instituting a blockade. ${ }^{263}$ Although Congress had not explicitly declared war, it had, in that instance, adopted a statute that ratified the Emancipation Proclamation. Consisting of two executive orders, the proclamation explicitly rested on the 
president's military power to seize and confiscate enemy resources in times of military engagement. ${ }^{264}$ Regardless of the proclamation, however, the Court considered the president's actions constitutional.

The Prize Cases stand, first, for the proposition that the president's power to respond to military attacks on the United States does not depend on Congress having declared war. This is part of the executive power retained by the president, confirmed in the Commander-in-Chief Clause. Second, regardless of whether a war is formally declared, the president, as commanderin-chief, possesses the full executive power with respect to the conduct of military hostilities.

Would, however, responding to a pandemic potentially stemming from a biological weapons attack qualify as military hostilities?

It may be, at the outset of a pandemic, nearly impossible to ascertain whether the spread of the disease is due to natural causes, terrorist attack, or an act of war levied by another country against the United States. Consider plague. Long a mainstay in biological weapons arsenals, the disease is also naturally occurring. A traveler from Algeria could contract the disease, return to the United States, attend community events, and eventually present at a hospital for treatment. Initially, it may not be clear whether the individual accidentally contracted the disease or is being used as a vector by which to spread it throughout the country and to take out U.S. medical facilities. In either case, the effects on the country from the carrier's initial actions would be largely the same. Either way, significant resources may be necessary to mitigate the effects of the disease.

What authorities does the president have in such a circumstance? Can the president use the military—and to what extent? As a constitutional matter, a stronger case can be made for Article II powers in the event of known biological weapons usage and, particularly, known use 
of biological agents by another country. It may be, however, impossible to know at the outset if such circumstances hold. Should the executive be given power in anticipation of such a result? If not, does it make sense to leave the determination of when Article II comes into play in the hands of the executive branch — which then benefits from a significant expansion in its authority? There is a certain conflict of interest in allowing the president to essentially determine the contours of executive power. If there is no overt enemy in regard to which war can be declared, then further questions arise with regard to what limits, if any, can be placed on the executive.

This leads naturally to the question of whether Congress would need to pass, for instance, an explicit authorization for the use of the military to support quarantine and isolation. On at least three occasions the legislature has authorized use of the armed forces short of declaring war. ${ }^{265}$ While argument can be made that this still falls short of the constitutional provisions that require Congress to declare war-instituted precisely to set the bar high and to avoid use of the military absent legislative approval — it may be the best vehicle to ensure constitutional compliance. This analysis, however, still begs the question of the specific role of the military on U.S. soil.

\section{B. Role of the Military}

The 1807 Insurrection Act governs the president's authority to deploy troops within domestic bounds. ${ }^{266}$ Like the Stafford Act, the statute requires that whenever an insurrection occurs, "the President may, upon the request of the legislature or of its governor if the legislature cannot be convened, call into Federal service such of the militia of the other States, in the number requested by that State, and use such of the armed forces, as he considers necessary to suppress the insurrection." 267 Absent a governor's request, in the event that the president "considers that unlawful obstructions, combinations, or assemblages, or rebellion against the 
authority of the United States, make it impracticable to enforce the laws of the United States... by the ordinary course of judicial proceedings," the militia and armed forces can be used. ${ }^{268}$ Such measures, however, are explicitly directed to suppressing "any insurrection, domestic violence, unlawful combination, or conspiracy," where such violence interferes with execution of use laws or operation of the courts. ${ }^{269}$

A few observations about this language can be made. First, the mere incidence of sickness - natural pandemic or biological weapons-related in origins - is insufficient to justify military intervention. The statute explicitly requires an actual breakdown in law and order. Hypothetical risks are insufficient. Second, even if violence does result from an epidemic, the role of the military appears to be limited to suppressing the violence-not responding to the medical needs of the population by, for instance, distributing and administering vaccines, transporting ill patients, testing blood samples, treating the ill, performing quarantine and isolation on civilians, establishing triage stations, and the like. The changes made to the Insurrection Act by the 2007 Defense Authorization Act would have allowed the president to federalize the National Guard to respond to a "natural disaster, epidemic or other serious public health emergency, terrorist attack or incident," in the event that the president unilaterally determined that "authorities of the state or possession are incapable of maintaining public order." But these were precisely the changes subsequently rejected by Congress.

Even considering the role of the military in a law enforcement capacity, it is to be remembered that the Framers evinced considerable concern about standing armies. ${ }^{270}$ Following Reconstruction, such concerns became enshrined in the Posse Comitatus Act, which significantly limited the powers of the federal government to use the armed forces to conduct law enforcement. ${ }^{271}$ Under the Posse Comitatus Act, "Whoever, except in cases and under 
circumstances expressly authorized by the Constitution or Act of Congress, willfully uses any part of the Army or the Air Force as a posse comitatus or otherwise to execute the laws shall be fined under this title or imprisoned not more than two years, or both." ${ }^{272}$ Congress later added proscription against use of armed forces to make arrests or conduct searches and seizures. Most recently, Congress expressed its sense reaffirming the continued importance and applicability of the Posse Comitatus Act when it established the Department of Homeland Security, leaving open the use of the armed forces for law enforcement when authorized by act of Congress or the president to fulfill constitutional obligations to respond "in time of war, insurrection, or other serious emergency.",273

This language does constitute a statutory, not a constitutional, limit. Indeed, as a constitutional matter, it could be argued that the Posse Comitatus Act is itself an unconstitutional limit on the powers of the president.

In light of the statute, however, two distinct challenges could be brought to the role of the military in establishing and enforcing quarantine and isolation measures in response to either naturally occurring pandemic or the spread of an engineered agent: (a) the type of activities in which Title 10 troops engage in the performance of quarantine; and (b) the conditions under which the government may federalize Title 32 troops, removing them from state control. The courts have yet to rule on these difficult questions.

C. Marking the Boundaries of the Commerce Clause

Setting aside for the moment the constitutional issues embedded in linking and placing pandemic disease and biological weapons within a national security framework, broader constitutional questions about the extent to which the federal government can act in public health persist. Public health law lies at the heart of state police powers. Questions remain about the 
extent to which Commerce Clause authorities empower the federal government to legislate in this realm. The Tenth Amendment itself remains silent on the precise scope of the powers reserved to the states - or to the people. ${ }^{274}$ Precious little consideration of the contours of the authorities reserved to the states can be found in the papers of those present at the constitutional convention. ${ }^{275}$ Yet what becomes clear from the historical exposition of quarantine provisions in the nineteenth century, discussed above, is that their impact on commerce was insufficient to altogether wrench them from the grasp of state power.

Chief Justice Marshall thus noted in 1824 that quarantine lay at the very heart of those authorities reserved to the states. ${ }^{276}$ Thirty years later, Justice Grier explained that internal police powers, which included every law introduced for the preservation of public health, "are not surrendered by the states, or restrained by the Constitution of the United States, and that consequently, in relation to these, the authority of a state is complete, unqualified, and conclusive." 277 No federal regulation could "supersede or restrain their operations, on any ground of prerogative or supremacy." ${ }^{278}$ Quarantine, whatever its impact on commerce, resided at the core of state police power:

[Q]uarantine laws, which protect the public health, compel mere commercial regulations to submit to their control. They restrain the liberty of the passengers, they operate on the ship which is the instrument of commerce, and its officers and crew, the agents of navigation. They seize the infected cargo and cast it overboard. The soldier and the sailor, though in the service of the government, are arrested, imprisoned, and punished for their offenses against society. ... All these things are done not from any power which the states assume to regulate commerce or to interfere with the regulations of Congress, but because police laws for the preservations of health, prevention of crime, and protection of the 
public welfare must of necessity have full and free operation according to the exigency which requires their interference. ${ }^{279}$

The exigencies of the social compact required that such state laws "be executed before and above all others." 280

Accordingly, in 1868 Thomas Cooley explained, "Numerous ... illustrations might be given of the power in the States to make regulations affecting commerce, and which are sustainable as regulations of police. Among these," he continued, "quarantine regulations and health laws of every description will readily suggest themselves, and these are or may be sometimes carried to the extent of ordering the destruction of private property when infected with disease or otherwise dangerous. ${ }^{, 281}$ Such regulations, at least with regard to Commerce Clause considerations, "generally passed unchallenged." 282 In 1886 the influential legal commentator Christopher Tiedeman further noted:

This police power of the State extends to the protection of the lives, limbs, health, comfort and quiet of all persons, and the protection of all property within the State. According to the maxim, sic utere tuo, ut alienum non laedas, it being of universal application, it must of course be within the range of legislative action to define the mode and manner in which every one may so use his own as not to injure others. Any law which goes beyond that principle, which undertakes to abolish rights, the exercise of which does not involve an infringement of the rights of others, or to limit the exercise of rights beyond what is necessary to provide for the public welfare and the general security, cannot be included in the police power of the government. ${ }^{283}$

That same year, as a matter of case law, Morgan's Steamship, followed in 1902 by Compagnie Francaise, acknowledged the strong role of the states in public health—while leaving the door 
open to federal preemption. In 1905 Jacobson placed even more weight on the side of the states, reiterating Marshall's position in Gibbons.

As a matter of constitutional law, then, despite a significant impact on commerce, it appears that the exercise of quarantine by the states is to a great extent protected. This does not mean that the federal government has no role to play. Morgan's Steamship and Compagnie Francaise, as noted above, both left open the possibility of preemption. Encouraged by the Court's position, Congress did begin to legislate, and in 1963 the Court upheld challenge to federal quarantine. ${ }^{284}$ At that time, the World Health Organization had declared Stockholm to be a smallpox-infected area. When a passenger from Stockholm arrived in the United States and was not able to produce documentation showing that vaccination had taken place, the Public Health Service quarantined the passenger for fourteen days. The District Court noted that the federal government had acted in good faith, that the individual had had a history of unsuccessful vaccinations, and that detention during the incubation period was required to determine whether the individual had been infected. The case, however, left unanswered the structural questions that bedevil the line between state and federal authorities. While the federal government may be able to preempt the states in some areas related to quarantine, the authority to impose the same at a state level is still firmly rooted in the powers reserved to the states.

The uneasy compromise that has been reached is that quarantine provisions related to the country's borders, such as along the coastlines or on the Canadian or Mexican border, fall firmly within the federal domain. But what happens when every airport, seaport, and bus or train station becomes a point of entry or interstate transfer? Does the federal government have the authority to quarantine and isolate all travelers? This is the current position of the federal government for interior quarantine - that is, coming into contact with individuals who may be about to move 
between states. But is this a meaningful limit on federal power? While one could devise a remote mountain scenario, where such contact would be unlikely, in an age of mass transit, such cases certainly represent the exception, not the rule. Would it allow the federal government to place a cordon sanitaire around a city, absent state acquiescence? At some point such authority eviscerates the power reserved to the states with regard to quarantine, in the process raising concerns well known to the founders about the concentration of authority in federal hands.

Moreover, is the test adopted by the federal government—coming into contact with interstate travelers - the correct one? For instance, what level of impact on commerce is necessary? Does it matter what the disease is? Under executive order, pandemic influenza is now included. Does that mean that every flu season the federal government could impose quarantine and isolation on citizens? What about the manner in which the disease is disseminated? Does it matter if it is criminal in nature? Would, for instance, medical measures aimed at mitigating the salmonella outbreak at salad bars in Oregon satisfy Commerce Clause considerations-or would that fall within state police powers? While the authority of Congress appeared to be expanding in this area throughout much of the twentieth century, more recent cases-namely US v. Lopez and US v. Morrison, suggest a possible contraction.

D. Limits of the Necessary and Proper Clause

A final structural question presents itself - that is, even if we have seen limits on the Commerce Clause, recent interpretations of the Necessary and Proper Clause give effect to broader congressional control of interstate commerce. That clause gives Congress the authority to "make all Laws which shall be necessary and proper for carrying into Execution the foregoing Powers, and all other Powers vested by this Constitution in the Government of the United States, or in any Department or Officer thereof." ${ }^{285}$ Gonzales v. Reich proved significant in this regard, 
upholding federal efforts to override California's legalization of cannabis for medical purposes. Justice Scalia distinguished the case from Lopez and Morrison, writing, "Congress may regulate noneconomic intrastate activities only where the failure to do so 'could ... undercut' its regulation of interstate commerce."

US v. Comstock extended this line of reasoning: in a 7-2 decision written by Justice Breyer, the Court upheld federal law allowing the government to indefinitely detain "sexually dangerous" federal prisoners following completion of their sentences. ${ }^{286}$ The majority considered continued detention as "necessary and proper" to implementing congressional power to operate a penal system and act "as the custodian" of prisoners held within it. ${ }^{287}$

The decision, however, raises questions about how quarantine would fare in a similar context. The Court adopted a rational basis test, concluding that the clause allows any exercise of authority that "constitutes a means that is rationally related to the implementation of a constitutionally enumerated power." ${ }^{288}$ In a separate concurrence Justice Kennedy argued against the use of this test.

The terms "rationally related" and "rational bases" must be employed with care, particularly if either is to be used as a stand-alone test. The phrase "rational basis" most often is employed to describe the standard for determining whether legislation that does not proscribe fundamental liberties nonetheless violates the Due Process Clause.... The phrase ... should not be extended uncritically to the issue before us. ${ }^{289}$

While the immediate law at question in Comstock was "a discrete and narrow exercise of authority over a small class of persons already subject to the federal power," involving "little intrusion upon the ordinary processes and powers of the states, ${ }^{, 290}$ the same would not be true of a broad federal authority over state public health. Justice Alito, like Kennedy, expressed concern 
in his concurrence about giving Congress "carte blanche" via the Necessary and Proper Clause. ${ }^{291}$ Justice Thomas wrote an even more scathing dissent, much of which was joined by Justice Scalia, suggesting that "Congress may act under [the Necessary and Proper clause] only when its legislation 'carr[ies] into Execution' one of the Federal Government's enumerated powers. ${ }^{292}$

Just as "[no] enumerated power in Article I, $\S 8$ [of the Constitution], expressly delegates to Congress the power to enact a civil-commitment regime for sexually dangerous persons ... , ${ }^{293}$ no specific enumerated constitutional power gives the federal government authority over public health. To the contrary, since the founding, this has been considered to be reserved to the states via the Tenth Amendment. Nor, under Justice Thomas's view, could quarantine provisions be upheld simply because Congress has passed other laws more directly affecting Commerce. ${ }^{294}$ Instead, such statutes would be valid only insofar as they facilitated the use of the previous law to implement Congress's enumerated authorities.

In Comstock, the majority considered five factors that contributed to their decision: We take these five considerations together. They include: (1) the breadth of the Necessary and Proper Clause, (2) the long history of federal involvement in this arena, (3) the sound reasons for the statute's enactment in light of the government's custodial interest in safeguarding the public from dangers posed by those in federal custody, (4) the statute's accommodation of state interests, and (5) the statute's narrow scope. Taken together, these considerations lead us to conclude that the statute is a "necessary and proper" means of exercising the federal authority that permits Congress to create federal criminal laws, to punish their violation, to imprison violators, to provide appropriately for 
those imprisoned, and to maintain the security of those who are not imprisoned but who may be affected by the federal imprisonment of others. ${ }^{295}$

What is less than clear, as Justice Thomas points out in his dissent, is exactly how the five-point test should be applied in the future. ${ }^{296}$ How would this reasoning transfer over to the quarantine realm? In regard to the second consideration, for instance, there is a long history not of federal involvement in this arena but of state and local involvement. The majority's third consideration (sound reasons for enacting the statute in light of the government's responsibilities) may reflect in a strong federal interest in safeguarding the country from pandemic disease; but the fourth consideration, the extent to which state interests are accommodated, may constrict in the evolution of these provisions. The direction that the most recent quarantine measures are taking may run afoul of the factors laid out in Comstock. Whether the Court's jurisprudence in this area will allow greater or lesser leeway remains to be seen.

\section{E. Risk of Distorting the Most Effective Responses to Public Health Concerns}

We turn then to two policy concerns that mark the most current shifts with regard to public health. The first is whether allowing the biological weapons conversation to upstage public health — that is, set the agenda for how to respond to disease - is a good idea.

The United States spends twice as much annually on biological terrorism as on public health. But the public health threats are substantial: millions of people die from naturally occurring disease each year. ${ }^{297}$ Communicable diseases, such as respiratory infections, HIV/AIDS, diarrheal diseases, tuberculosis, malaria, measles, tetanus, meningitis, and hepatitis B, as well as food-borne bacterial infections like salmonella and Escherichia coli, can be devastating. In contrast, the number of people that have died from the dissemination of biological agents is extremely small. The emphasis on biological agents risks pulling the focus away from 
more likely threats. Do we really want our public health structure to depend on funding and planning for biological weapons? Does it make sense to take the focus away from the more mundane, but potentially equally or even more devastating, diseases, merely because ordinary pandemics require no human intervention for their construction and dissemination? If we allow biological weapons to provide the focus, then everything from the type of disease monitored and the types of vaccines and prophylactics developed, to the nature of health surveillance may alter- even as resources become consumed that could otherwise go to better use.

The coupling of biological weapons and public health also risks shifting the relationship between the federal government and the citizens. The national security dialogue is essentially an adversarial one - in keeping with the pace of weaponization, it suggests that any one individual could pose a devastating threat to the country. It thus treats individual citizens as potential adversaries. But we currently have a public health system built on voluntary compliance. What happens when you create an adversarial relationship between citizens and the government—and then forcibly attempt to restrain their movement? What happens to voluntary reporting, general vaccination, and cooperation in the event of a public health emergency?

The recent example of CIA actions in Pakistan is here instructive. The agency, under the guise of a vaccination program, collected DNA samples from individuals living in Pakistan. Billed as a free clinic to prevent hepatitis B, the actual aim was to ascertain the presence of Bin Laden family members. ${ }^{298}$ Health care workers are now braced for the backlash, as Pakistanis refuse to come forward for vaccination, because of suspicion that any vaccination program is being orchestrated by the United States as part of its campaign. ${ }^{299}$ The risk of prioritizing national security is that public health, as a consequence, directly suffers. 
While the vaccination campaign took place overseas, the United States has a long history of resistance to invasive federal actions. By placing public health in an adversarial framing, the risk arises of feeding into this deep-seated suspicion of coercive power and, in the process, undermining public health across the board. The movement to include military actors as a way to implement such authorities further exacerbates the problem.

Added to this are concerns about the more likely occurrence of naturally occurring disease. Biological weapons are difficult to produce and even harder to disseminate. Does it make sense to orient our public health system around the lower risk event—particularly when equally devastating consequences may follow from pandemic disease?

F. Quarantine and Isolation under Fire

The second and final policy consideration relates more specifically to the use of quarantine and isolation as a response. While grounded in historical precedent, it is not at all clear that quarantine — and, specifically, cordon sanitaire —works. Yet, even as states bemoaned the continued rampages of disease and the ineffectiveness of prior quarantine provisions, they introduced yet broader authorities and more stringent penalties. During the Spanish influenza epidemic, American towns otherwise cut off from the outside world found that disease nevertheless traveled into their bounds - arriving, for instance, via the post, on the outside of packages entering their space. There is a legitimate question, in such an age of such mobility and connectedness, whether cordon sanitaire can even be accomplished. ${ }^{300}$ Indeed, the U.S. influenza plan specifically notes that quarantine may be particularly ineffective for stopping the spread of the disease. It is for this reason that, unlike the United States, the United Kingdom eschews any use of quarantine for pandemic influenza. ${ }^{301}$ 
The strongest argument that could be made for it is that quarantine and isolation may slow the spread of disease. This is an important consideration. Time may be critical in allowing the government to amass and distribute vaccines, prophylactics, and other medications. And lives are at stake. Yet even granting that quarantine may retard the disease's advance, what unintended consequences might follow? For example, what happens to the provision of basic services—such as emergency medical care, policing, electricity, and sanitation-when population flows are severely limited? What about access to other medical services, or the economic effect of bringing business, government, and education to a standstill? In a severely weakened economy, the country's ability to respond to other threats is similarly diminished. What happens when citizens refuse to abide by the quarantine provisions? How might this undermine state control? And what happens when you add the military to a civilian mix - in light of very different rules of engagement from the ordinary law enforcement framing?

It may be, of course, that the proliferation of quarantine authorities are merely cosmetic - that the federal government does not intend to actually use the powers it is seekingthat they are, indeed, an outmoded nod to a history based on unsound science. If this is the case, however, then why even have such powers on the books? For the presence of the laws bring with them their own form of political and legal legitimacy, which may encourage their use. And the political will to use such powers may well significantly alter in a crisis.

\section{Concluding Remarks}

Two major shifts have occurred with regard to the evolution of measures designed to counter pandemic disease and biological weapons. The first shift, which solidified in the early 20th century, carved out a role for the federal government in preventing the importation of 
disease into the country and in allowing for federal agencies to stem the transfer of disease between states through the use of quarantine and isolation. The second shift moved pandemic disease and biological weapons into a national security realm, linking the two in terms of institutions, identification, and approach. In this move, quarantine and isolation appear central, and growing attention is being paid to the role of the military in executing the federal measures.

As a constitutional matter, the first shift rested on an uneasy compromise between the police powers reserved to the states through the Tenth Amendment and the Commerce Clausean agreement forged through use of the Spending Clause. The second shift, however, rests on shakier constitutional grounds. Significant questions regarding individual rights remain unanswered, even as four structural problems present themselves: the treatment of public health within war powers, the role of the military on domestic soil, the limits of Commerce Clause authority, and the extent to which the Necessary and Proper Clause empowers the federal government to act. Added to this are concerns about the wisdom of allowing the threat of biological weapons to set the agenda for public health, and the effectiveness of quarantine and isolation as a response. These issues warrant further inquiry.

Notes

Special thanks to Georgetown Law's Laura Bedard and Todd Venie, for their extraordinary help in locating materials used in this chapter. Professors Larry Gostin, John Norton Moore, and Steven Vladeck provided particularly thoughtful remarks on the text, as did participants in the GW Foreign Relations Colloquium, the Potomac Legal History Roundtable, and the Georgetown Law Faculty Workshop. 
${ }^{1}$ See, e.g., Julian Perry Robinson, The Problem of Chemical and Biological Warfare: A Study of the Historical, Technical, Military, Legal and Political Aspects of CBW, and Possible Disarmament Measures, Vol. I: The Rise of CB Weapons (1971); Robert Koenig, The Fourth Horseman: The Tragedy of Anton Dilger and the Birth of Biological Terrorism (2008) (discussing German use of anthrax and glanders to target livestock shipped to U.S. forces in World War I); Igor V. Domaradskij, Biowarrior: Inside the Soviet/Russian Biological War Machine (2003) (discussing the development of the Russian biological weapons program); National Security Decision Memorandum 25, United States Policy on Chemical Warfare Program and Bacteriological/Biological Research Program, from the National Security Advisor, Henry Kissinger, to the Vice President, the Secretary of State, and the Secretary of Defense, etc. (November 25, 1969), available at http://www.gwu.edu/ nsarchiv/NSAEBB/NSAEBB58/RNCBW8.pdf; and National Security Decision Memorandum 44, United States Policy on Toxins, from the National Security Advisor, Henry Kissinger, to the Vice President, Secretary of State, Secretary of Defense, etc. (February 20, 1970), available at http://www.gwu.edu/ nsarchiv/NSAEBB/NSAEBB58/RNCBW20.pdf (discussing the U.S. biological weapons program); S. H. Harris, Factories of Death: Japanese Biological Warfare 1932-45 and the American Cover-up (1994).

${ }^{2}$ See, e.g., Protocol for the Prohibition of the Use in War of Asphyxiating, Poisonous or Other Gases, and of Bacteriological Methods of Warfare, June 17, 1925, 26 U.S.T. 571, 94 L.N.T.S. 65 ("Whereas the use in war of asphyxiating, poisonous or other gases, and of all analogous liquids, materials or devices, has been justly condemned by the general opinion of the civilized world; and Whereas the prohibition of such use has been declared in Treaties to which the majority of Powers of the world are Parties ... [we] Declare: That the High Contracting 
Parties, so far as they are not already Parties to Treaties prohibiting such use, accept this prohibition, agree to extend this prohibition to the use of bacteriological methods of warfare and agree to be bound as between themselves according to the terms of this declaration) (100 states party); Convention on the Prohibition of the Development, Production and Stockpiling of Bacteriological (Biological) and Toxin Weapons and on Their Destruction, April 10, 1972, 26 U.S.T. 583, 1015 U.N.T.S. 163 (Each State Party to this Convention undertakes never in any circumstances to develop, produce, stockpile, or otherwise acquire or retain: (1) Microbial or other biological agents, or toxins whatever their origin or method of production, of types and in quantities that have no justification for prophylactic, protective or other peaceful purposes. (2) Weapons, equipment or means of delivery designed to use such agents or toxins for hostile purposes or in armed conflict.") (144 states party). But see, e.g., Jonathan B. Tucker, "Historical Trends Related to Bioterrorism: An Empirical Analysis," Emerging Infectious Diseases, Table 1, available at http://www.cdc.gov/ncidod/eid/vol5no4/tucker.htm (discussing R.I.S.E., an ecoterrorist group that emerged in 1972 with the goal of killing off most of humanity to prevent the destruction of nature. The group began by targeting the residents of states surrounding Chicago. Members developed eight microbial pathogens with the intent to disperse them by aircraft, contaminating municipal water supplies.)

${ }^{3}$ See, e.g., "National Security Strategy of the United States of America," September 2002, available at http://www.whitehouse.gov/nsc/nss.pdf. ("With the collapse of the Soviet Union and the end of the Cold War, our security environment has undergone profound transformation. ... [N]ew deadly challenges have emerged from rogue states and terrorists. ... [T] he nature and motivations of these new adversaries, their determination to obtain destructive powers hitherto available only to the world's strongest states, and the greater likelihood that they 
will use weapons of mass destruction against us, make today's security environment more complex and dangerous.")

${ }^{4}$ Title XIV, National Defense Authorization Act for FY 1997.

${ }^{5}$ Statement of the Hon. Richard G. Lugar, Senator (R-IN), to the House Military Research and Development Subcommittee, Hearing on the Security of Russian Nuclear Weapons, October 2, 1997, available at http://www.fas.org/spp/starwars/congress/1997_h/h9710021.htm.

${ }^{6}$ Ibid.

${ }^{7}$ Gillian Flaccus, “Oregon Town Never Recovered from Scare," Associated Press, the Rick A. Ross Institute for the Study of Destructive Cults (Controversial Groups and Movements Website, October 19, 2001), available at http://www.rickross.com/reference/rajneesh/rajneesh8.html.

${ }^{8}$ Ibid.

${ }^{9}$ Tucker, "Historical Trends Related to Bioterrorism," supra note 2.

${ }^{10}$ Jessica Eve Stern, "Larry Wayne Harris," in Toxic Terror: Assessing Terrorist Use of Chemical and Biological Weapons, ed. Jonathan B. Tucker (1998), 227-46.

${ }^{11}$ Tucker, "Historical Trends Related to Bioterrorism," supra note 2, Table 1. See also Stern, "Larry Wayne Harris," supra note 10.

${ }^{12}$ J. Parker-Tursman, "FBI Briefed on District's Terror Curbs," Pittsburgh Post-Gazette, May 5, 1999; and Tim Weiner, "Reno Says U.S. May Stockpile Medicine for Terrorist Attacks," New York Times, April 23, 1998, A:12.

${ }^{13}$ Ibid.

${ }^{14}$ Ibid. 
${ }^{15}$ Center for Nonproliferation Studies, “WMD Terrorism Database," Monterey Institute for International Studies, password protected database available at http://cnswmd.miis.edu/wmdt//.

${ }^{16}$ Remarks by Homeland Security secretary Michael Chertoff at the Stanford Constitutional Law Center's Germ Warfare, Contagious Disease, and the Constitution Conference, Washington, DC, April 11, 2008, available at http://www.dhs.gov/xnews/speeches/sp_1208283625146.shtm ("We know, for example, in the late 1990s, al Qaeda became focused on developing a biological weapons program. After the invasion of Afghanistan, we determined that there was a low-tech facility in Kandahar, which was actually aimed at producing anthrax and the purpose obviously was to create a weapon.")

${ }^{17}$ American Association for the Advancement of Science, "Science and Security in the Post-9/11 Environment: Bioterrorism," available at http:/www.aaas.org/spp/post911/agents/.

${ }^{18}$ President Bush, West Point, New York, June 1, 2002, cited in "National Security Strategy of the United States of America," supra note 3.

${ }^{19}$ See, e.g., Richard A. Falkenrath, Robert D. Newman, and Bradley A. Thayer, America's Achilles' Heel: Nuclear, Biological, and Chemical Terrorism and Covert Attack (1998); Philip B. Heymann, Terrorism and America: A Commonsense Strategy for a Democratic Society (1998); Bruce Hoffman, Inside Terrorism (1998); Brad Roberts, ed., Terrorism with Chemical and Biological Weapons: Calibrating Risks and Responses (1997); Jessica Stern, The Ultimate Terrorists (1999).

${ }^{20}$ The Australian mousepox case is here instructive: every four years, Australia suffers from a rodent infestation that devastates the crops and takes a considerable toll on the gross domestic product of the country. In 1998 some Australian scientists decided to try to engineer a 
biological disease — they did not want to kill the rodents, because this would have created a problem with disease. Instead, they chose mousepox, a highly virulent disease, and attached a secondary disease to make it impossible for the rodents to reproduce. After extensive experiments, they found, much to their surprise, that in making the disease effective even against rats with immune systems that rejected mousepox, they ended up with a disease that was 100 percent virulent—and fatal. Mousepox is closely linked to smallpox—one of the most devastating diseases in the history of humankind, killing 500 million people in the twentieth century alone. The researchers initially decided not to publish the information; but after the Australian military dragged its heels, they placed a paper in Science, an American journal. Although initially received with minimal discussion, following the anthrax mailings in autumn 2001, the incident attracted the attention of the president and members of Congress, alarmed that the experiment—with such devastating results—-required just three feet of countertop and a basic knowledge of microbiology. For more discussion of this incident, see Laura K. Donohue, The Cost of Counterterrorism: Power, Politics, and Liberty (2008), ch. 5.

${ }^{21}$ Highly Pathogenic avian influenza virus of type A of subtype H5N1[HPAI A(H5N1)] = causative agent of H5N1,commonly known as "avian influenza." Kristin Choo, "The Avian Flu Time Bomb: The Legal System Will Play a Key Role in Planning the Response to a Possible Onslaught of the Virus," A.B.A. J., November 2005, available at http://www.cphp.pitt.edu/PDF/THE\%20AVIAN\%20FLU\%20TIME\%20BOMB.pdf.

${ }^{22}$ Writing Committee of the World Health Organization, “Avian Influenza A (H5N1) Infection in Humans," N. Engl. J. Med. 354, no. 8 (2006): 884, available at http://content.nejm.org/cgi/content/full/353/13/1374; and Choo, "The Avian Flu Time Bomb," supra note 21. 
${ }^{23}$ There appear to be a handful of cases where the disease may have been transmitted between people (for example, mother to child, and patient to nurse). These, however, appear to be unique. Writing Committee of the World Health Organization, “Avian Influenza A (H5N1) Infection in Humans," supra note 22, p. 884.

${ }^{24}$ Frederick F. Cartwright, "Pandemics Past and Future," in Disease in Ancient Man: An International Symposium, ed. Gerald D. Hart (Toronto, 1983), 167-80.

${ }^{25}$ Fred R. van Hartesveldt, ed., The 1918-19 Pandemic of Influenza: The Urban Impact in the Western World (1992) (estimates at least 40 million); Niall Johnson, Britain and the 191819 Influenza Pandemic \{\{Author: Please supply full pub. info.\}\}, 103, (estimating up to 100 million).

${ }^{26}$ As of January 30, 2008, the World Health Organization reported 224 deaths out of 357 cases of H5N1 in humans (62.74 percent). "Cumulative Number of Confirmed Human Cases of Avian Influenza A/(H5N1) as Reported to the World Health Organization,” January 30, 2008, available at http://www.who.int/csr/disease/avian_influenza/country/cases_table_2008_01_30/en/index.html. ${ }^{27}$ See, e.g., Ira M. Longini et al., "Containing Pandemic Influenza at the Source," \{\{Author: Vol. no.?\}\}Science (2005): 1083-87; Thomas Luke, Timothy Halenkamp, and Edward Kilbane, "Naval Quarantine: Impervious to Epidemics of Virulent Disease,” U.S. Naval Inst. Proc. 132, no. 7 (July 1, 2006): 48.

${ }^{28}$ See Angie A. Welborn, "Federal and State Isolation and Quarantine Authority," CRS Report, January 18, 2005, 1, available at http://www.fas.org/sgp/crs/RL31333.pdf. 
${ }^{29}$ World Health Organization, "Summary of Probable SARS Cases with Onset of Illness from 1 November 2002 to 31 July 2003," available at http://www.who.int/csr/sars/country/table2004_04_21/en/index.html.

${ }^{30}$ See, e.g., Michael T. Osterholm, "Preparing for the Next Pandemic," Foreign Affairs (July/August 2005); and Choo, “The Avian Flu Time Bomb,” supra note 21.

${ }^{31}$ Graeme T. Laurie and Kathryn G. Hunter, "Mapping, Assessing and Improving Legal Preparedness for Pandemic Flu in the United Kingdom," Medical Law Int'l, (2009): 101, 103.

${ }^{32}$ See http://www.nature.com/news/specials/swineflu/index.html.

${ }^{33}$ See, e.g., USA PATRIOT Act, $§ 817$ (expanding the biological weapons statute to make it an offense to knowingly possess any biological agent, toxin, or delivery system that is not reasonably justified for peaceful purposes; creating category of persons restricted from dealing in select agents); Homeland Security Act of 2002, Pub. L. No. 107-296, 116 Stat. 2135 (2003); Public Health Security and Bioterrorism Preparedness and Response Act of 2002, Pub. L. No. 107-88, 116 Stat. 294 (2002), codified in scattered sections of 7 U.S.C., 18 U.S.C., 21 U.S.C., 29 U.S.C., 38 U.S.C., 42 U.S.C., and 47 U.S.C. (2002) (placing controls on dangerous biological agents); CDC associated regulations (specifying over eighty biological agents considered threatening to public health and safety or animal and plant health; and creating the Select Agents Program: any facilities/individuals in possession of listed agents must register with CDC or Animal and Plant Health Inspection Service. Scientists handling must undergo security clearances, fingerprinting.); 2004 Intelligence Reform and Terrorist Prevention Act; [giving Secretary of Homeland Security authority (and money— $\$ 250$ million) to obtain equipment to detect nonmetallic, chemical, biological, and radiological weapons and explosives, in all forms, on individuals and their personal property at airport screening checkpoints (§4018); requiring 
report from DHS on the procedures in place to address BW threats in incoming air cargo (§4053); Subtitle I — Weapons of Mass Destruction Prohibition Improvement Act of 2004 expands categories of restricted persons subject to prohibitions relating to select agents, enhances prosecution of WMD offenses (\$6802); making it illegal to handle the variola virus outside of direct authorization by HHS (§6906)]; 2004 Intelligence Reform and Terrorist Prevention Act and Project BioShield Act of 2004, P.L. 108-276 (“To amend the Public Health Service Act to provide protections and countermeasures against . . . agents that may be used in a terrorist attack against the United States"; directing Secretary of DHS to continually monitor BW threats; directing DOJ to provide stockpile security and quarantine enforcement upon request of HHS). For regulatory changes see, e.g., 42 CFR Parts 70 and 71, under Public Health Service Act (42 U.S.C. 264-271), Proposed under 25 U.S.C. 198, 231, and 1661; 42 U.S.C. 243, 248, 249, $264-$ 72, and 2007. Federal Register 70, no. 229 (November 30, 2005): 71892-948.

${ }^{34}$ See, e.g., Homeland Security Presidential Directive 10, Biodefense for the 21 st Century, April 28, 2004, available at http://www.fas.org/irp/offdocs/nspd/hspd-10.html; "National Security Strategy of the United States of America," supra note 3; National Response Plan, 2002 National Strategy to Combat Weapons of Mass Destruction; and U.S. Homeland Security Council, National Strategy for Pandemic Influenza: Implementation Plan, May 2006, available at http://www.whitehouse.gov/homeland/nspi_implementation.pdf. [Hereinafter Implementation Plan]. More than $\$ 57$ billion has been spent on these initiatives. Spencer S. Hsu, “Modest Gains against Ever-Present Bioterrorism Threat," Washington Post, August 3, 2008, A10, available at http:/www.washingtonpost.com/wpdyn/content/article/2008/08/02/AR2008080201624_pf.html. See also Jennifer Gaudioso and 
Reynolds M. Salerno, "Biosecurity and Research: Minimizing Adverse Impacts," Science 304 (April 30, 2004).

${ }^{35}$ Homeland Security Act of 2002, Pub. L. No. 107-296, 116 Stat. 2135 (2003).

${ }^{36}$ U.S. Department of Homeland Security, "Emergencies \& Disasters, Planning \& Prevention," National Response Plan 1, available at http://www.dhs.gov/dhspublic/interapp/editorial/editorial_0566.xml.

${ }^{37}$ Pub. L. No. 107-188, 116 Stat. 294 (2002), codified in sections of 7 U.S.C., 18 U.S.C., 21 U.S.C., 29 U.S.C., 38 U.S.C., 42 U.S.C., and 47 U.S.C. (2002).

${ }^{38} 42$ CFR Parts 70 and 71, under Public Health Service Act (42 U.S.C. 264-71), Proposed under 25 U.S.C. 198, 231, and 1661; 42 U.S.C. 243, 248, 249, 264-72, and 2007. Federal Register 70 (229), November 30, 2005, 71892-71948.

${ }^{39}$ Dr. Jeff Runge, DHS Chief Medical Officer on Pandemic Preparedness, "Press Briefing on National Strategy for Pandemic Influenza Implementation Plan: One Year Summary,” July 17, 2007, available at http://www.whitehouse.gov/news/releases/2007/07/20070717-13.html. See also remarks of Dr. Venkayya, Special Assistant to the President for Biodefense, at "Press Briefing on National Strategy for Pandemic Influenza Implementation Plan: One Year Summary,” July 17, 2007, available at http://www.whitehouse.gov/news/releases/2007/07/20070717-13.html.

${ }^{40}$ Venkayya, "Press Briefing on National Strategy," supra note 39.

${ }^{41}$ In concert with the initiatives described in this paper, the federal government has provided the lead to state governments in updating and strengthening their laws governing quarantine and isolation. The president's 2002 National Strategy for Homeland Security listed review of quarantine authority as a priority for state governments. Office of Homeland Security, 
National Strategy for Homeland Security, June 2002, available at http://www.whitehouse.gov/homeland/book/nat_strat_hls.pdf. CDC, in turn, funded the Center for Law and the Public's Health at Georgetown and Johns Hopkins universities to develop a Model State Emergency Health Powers Act. (Model Act available at http://www.publichealthlaw.net/Resources/Modellaws.htm.) The idea was for states to tailor their statutes and regulations so that they could respond to novel threats. Written in 2001, by 2006, Model Act "introduced in whole or part through 171 bills or resolutions in forty-four (44) states, the District of Columbia, and the Northern Mariannas Islands. Thirty-eight (38) states [AL, AK, AZ, CA, CT, DE, FL, GA, HI, ID, IL, IN, IA, LA, ME, MD, MN, MO, MT, NV, NH, NJ, NM, NC, OK, OR, PA, RI, SC, SD, TN, TX, UT, VT, VA, WI, and WY] and DC have passed a total of 66 bills or resolutions that include provisions from or closely related to the Act." Center for Public Health and Law, "Legislative Status Update," available at http://www.publichealthlaw.net/Resources/Modellaws.htm\#TP. See also Lawrence O. Gostin et al., "The Law and the Public's Health: A Study of Infectious Disease Law in the United States," Colum. L. Rev. 99, no. 59 (1999): 102.

For purposes of this chapter, I use the terms "isolation" and "quarantine" in a manner consistent with the federal regulations adopted by the Centers for Disease Control in February 2013. "Isolation" is thus "the separation of an individual or group of individuals who are reasonably believed to be infected with a quarantinable communicable disease from others who are healthy in such a manner as to prevent the spread of the quarantinable communicable disease," while "quarantine" is "the separation of an individual or group of individuals who are reasonably believed to have been exposed to a quarantinable communicable disease, but who are not yet ill, from others who have not been so exposed, in such a manner as to prevent the 
possible spread of the quarantinable communicable disease." Federal Register, Vol. 77, No. 247 (Dec. 26, 2012), pp. 75885-75891 (Department of Health and Human Services proposing new definitions under 42 CFR 71); and Federal Register Vol. 78, No. 37, Feb. 25, 2013, p. 12622 (Department of Health and Human Services adopting final rule). See also Edward A. Fallone, "Preserving the Public Health: A Proposal to Quarantine Recalcitrant AIDS Carriers," B.U. L. Rev. 68, no. 24 (1988): 441 (defining isolation as "the separation of a known infected person or animal from others during the period of contagiousness in order to prevent the direct or indirect conveyance of the infectious agent" and quarantine as "the restriction of movement of a healthy person who has been exposed to a communicable disease in order to prevent contact with unexposed persons.”)

${ }^{42}$ Pub. L. No. 107-188, 116 Stat. 294 (2002), codified in scattered sections of 7 U.S.C., 18 U.S.C., 21 U.S.C., 29 U.S.C., 38 U.S.C., 42 U.S.C., and 47 U.S.C. (2002).

${ }^{43}$ Modifies 42 U.S.C. 264; Act June 12, 2002.

${ }^{44}$ Executive Order 13295: Revised List of Quarantinable Communicable Diseases, April 4, 2003.

${ }^{45}$ Executive Order 13375, April 1, 2005.

${ }^{46} 42$ CFR 70.6 and 71.3.

${ }^{47} 42$ CFR Parts 70 and 71, under Public Health Service Act (42 U.S.C. 264-71), Proposed under 25 U.S.C. 198, 231, and 1661; 42 U.S.C. 243, 248, 249, 264-72, and 2007. Federal Register 70, no. 229 (November 30, 2005): 71892-948.

${ }^{48}$ Federal Register 70, no. 229 (November 30, 2005): 71892.

${ }^{49}$ See, e.g., Briefing Memo for Subcomm. on National Security, Veterans Affairs, and International Relations, 
http://www.house.gov/reform/ns/web_resources/briefing_memo_july_23.htm (reporting on the evolution of the TOPOFF exercise in Denver, $\mathrm{CO}$, "The CDC advises that Colorado state borders be cordoned off to limit further spread of plague throughout the United States and other countries. Colorado officials express concern about their ability to get food and supplies into the state").

${ }^{50}$ Implementation Plan, supra note 36.

${ }^{51}$ HSPD 10 (writing: "[T]he Department of Defense will continue to ensure that ... our troops and our critical domestic and overseas installations are effectively protected against [biological] threats").

5210 U.S.C. $15, \S \S 331-35$.

${ }^{53}$ Amending 10 U.S.C. $\$ 333$.

${ }^{54}$ Letter to the Hon. Patrick J. Leahy, U.S. Senate, and the Hon. Christopher "Kit" Bond, U.S. Senate, February 5, 2007, from Co-leads on the National Guard, Governors Michael F. Easley and Mark Sanford, available at http://www.nga.org/portal/site/nga/menuitem.cb6e7818b34088d18a278110501010a0/?vgnextoid =edd8b31eb2990110VgnVCM1000001a01010aRCRD.

${ }^{55}$ Editorial, "Making Martial Law Easier," New York Times, February 19, 2007.

${ }^{56}$ See, e.g., Bipartisan Katrina report, stating that in regard to natural disasters, "[T]he role of the National Guard is critical in the maintenance of civil order, the provision of logistical support, and the coordination of rescue and relief effort." Steve Bowman, Lawrence Kapp, and Amy Belasco, CRS, “Hurricane Katrina: DOD Disaster Response,” September 19, 2005, available at http://www.fas.org/sgp/crs/natsec/RL33095.pdf; Alfred J. Sciarrino, “Part III: Epidemics, Natural Disasters and Biological Terrorism—-the Federal Response," Mich. St. U.J. 
Med. \& L. 10, no. 429 (2006): 426 ("The suggestion to use the military in a national emergency is not merely academic, as in the immediate aftermath of Katrina, Americans saw the breakdown of civilian leadership, especially by the Department of Homeland Security, charged with the primary responsibility of responding to 'a terrorist attack, natural disaster or other large-scale emergency,' and by FEMA, the lead agency under the Department of Homeland Security. Only the military offered a wide range of worthwhile assistance, including proper search and rescue measures; recovering the bodies of those killed in the storm or afterward; immediately attempting to bolster and secure the levees; providing for and delivering food, shelter, and water; and restoring law and order" [internal footnotes deleted].)

${ }^{57}$ U.S. House of Representatives, "A Failure of Initiative," Final Report of the Select Bipartisan Committee to Investigate the Preparation for and Response to Hurricane Katrina (2006), available at http://www.gpoaccess.gov/congress/index.html, p. 201.

${ }^{58}$ See, e.g., DOD Directive 6010.22, National Disaster Medical System, Jan. 21, 2003 (defining the military health system role); DOD Instruction 5154.06, Armed Services Medical Regulating, Oct. 20, 2011; Joint Publication 3-28, Defense Support of Civil Authorities, July 31, 2013, at V11-V14, available at http://www.dtic.mil/doctrine/new_pubs/jp3_28.pdf; Implementation Plan, supra note 32, at 12.

${ }^{59}$ See, e.g., Act to Prevent the Coming of Sickly Vessells, \&c., Abstract or Abridgment of the Laws made and past by William Penn Absolute Proprietary, and Governour in Chief of the Province of Pensilvania and Territories there unto belonging, with the Advice and Consent of the Free-men thereof in Generall-Assembly mett at New-Castle, October 14, 1700-November 27, $1700, *\{\{J o h n:$ asterisks??\}\}26 ("Whereas it hath been found, by sad experience that the coming and arriving of unhealthy vessels at the ports and towns of this province and territories, 
and the landing of their passengers and goods, before they have lain some time to be purified, have proved very detrimental to the health of the inhabitants of this province ..."). See also John B. Blake, "Yellow Fever in Eighteenth Century America," Bull. N.Y. Acad. Med. 44, no. 6 (June 1968): 674 (discussing the late seventeenth-century outbreak of yellow fever in Boston, Charleston, and Philadelphia, and the failure of containment measures there to prevent its spread to New York). For a more detailed exposition of the history of U.S. quarantine law, see Laura K. Donohue, "Biodefense and Constitutional Constraints," National Security and Armed Conflict Law Review (forthcoming)(comparing the evolution of quarantine law in the United States and United Kingdom).

${ }^{60}$ See, e.g., Records of the Governor and company of the Massachusetts Bay in New England, ed. Nathaniel B. Shurtleff, MD, Vol. II, 1642-49 (Boston, 1853); and Acts Relating to the Establishment of Quarantine of Massachusetts from the Settlement of the Colony of Massachusetts Bay to the Present Time (1881), 5 (on file with author).

${ }^{61}$ See, e.g., An Act to prevent infectious Distempers being brought into this Colony, and to hinder the spreading thereof (1755), Act XIII, in Laws, Statutes, Ordinances, and constitutions, Ordained, Made and Established by the Mayor, Aldermen, and Commonalty, of the City of New-York, Convened in Common Council for The good Rule and government of the Inhabitants and Residents of the said City, November 9, 1762.

${ }^{62}$ See, e.g., An Act to prevent sickly Vessels coming into this Government, in The Laws of the Province of Pennsilvania Collected into One Volume, By Order of the Governour and Assembly of the said Province, 1714, c. LXII, p. 19.

${ }^{63}$ An Act to prevent sickly Vessels coming into this Government, in Laws of the Government of New-Castle, Kent and Sussex, Upon Delaware, 1752, *67. 
${ }^{64}$ See, e.g., An Act to oblige infected ships and other vessels coming into this province to perform quarantine, Lib. HS. Fol. 655, ch. XXV, Nov. 1766, in The Laws of Maryland to which are Prefixed the Original Charter, with an English Translation, the Bill of Rights and Constitution, 1799. See also Charles V. Chapin, "History of State and Municipal Control of Disease," in A Half Century of Public Health (1921), 143; Ralph Chester Williams, The United States Public Health Service 1798-1950 (1951), 63.

${ }^{65}$ See, e.g., An Act to Prevent the Spreading of Infectious Sickness, 1712, in Acts and Laws of His Majesties Colony of Rhode-Island, and Providence-Plantations in America, pp. 6364 (on file with author).

${ }^{66}$ Order regulating the quarantine of vessels from the West Indies (March) 1647-48, *200, reprinted in Records of the Governor and Company of the Massachusetts Bay in New England, Vol. II, 237. See also Acts Relating to the Establishment of Quarantine of Massachusetts from the Settlement of the Colony of Massachusetts Bay to the Present Time, 5-7 (referring to the "First order of General Court, regulating Quarantine of vessels passed at a session of the General Court the first month [March] 1647 or 1648" and reprinting the order).

${ }^{67}$ Acts Relating to the Establishment of Quarantine of Massachusetts, from the Settlement of the Colony of Massachusetts Bay to the Present Time (Boston: Rockwell and Churchill, City Printers, 1881), 5-6 (on file with author). See also Records of the Governor and Company of the Mass. Bay in New England, Vol. II, 237. Brock C. Hampton, "Development of the National Maritime Quarantine System of the United States," Public Health Reports (1896-1970) 55, no. 28 (July 12, 1940): 1245. Hampton cites to Susan Wade Peabody, "Historical Study of Legislation Regarding Public Health in the States of New York and Massachusetts," J. Inf. Dis., Supp. no. 4 (February 1909) According to Hampton, the New York colony may have also 
implemented quarantine in the same year. For other sources citing the MA Bay Colony order, see Sidney Edelman, "International Travel and Our National Quarantine System," Temple Law Quarterly 37, no. 28 (1963): 29. There is discrepancy in the secondary literature about the exact date of the Massachusetts Bay order; some put it at 1647, others at 1648. Compare, e.g., Williams, The United States Public Health Service, 65; Lawrence O. Gostin, Public Health Law: Power, Duty, Restraint (2000), 205-6; Richard A. Goodman, Paul L. Kocher, Daniel J. O’Brien, and Frank S. Alexander, "The Structure of Law in Public Health Systems and Practice," in Richard A. Goodman et al., Law in Public Health Practice (2d ed, 2007), ch. 2, 46-51, 263; Chapin, supra note 66, p. 133. The original writes, "March 1647-1648." At the time, the start of Britain's governmental year did not line up with the Gregorian Calendar (dating from 1582), but, instead, it coincided with the Julian calendar, which began each year on March 25. By implication, this suggests that the discussion regarding quarantine and the subsequent order took place between January 1, 1648, and March 24, 1648, making 1648 the more likely date of the first quarantine order issued by the American colonies. The English government did not switch to the Gregorian calendar until 1752. See C. R. Cheney, ed., Handbook of Dates for Students of English History (London, 1978), 6-11. See also First Order of General Court, regulating Quarantine of vessels passed at a session of the General court the first month (March) 1647-48, *200, reprinted in Records of the Governor and company of the Massachusetts Bay in New England, Vol. II, 1642-1649 (Boston, 1853), 237; and Acts Relating to the Establishment of Quarantine of Massachusetts from the Settlement of the Colony of Massachusetts Bay to the Present Time, 5.

${ }^{68}$ Acts Relating to the Establishment of Quarantine of Massachusetts, from the Settlement of the Colony of Massachusetts Bay to the Present Time (Boston: Rockwell and Churchill, City 
Printers, 1881), 6 (on file with author). See also Records of the Governor and Company of the Mass. Bay in New England, Vol. 2, 237.

${ }^{69}$ Ibid., Acts Relating to the Establishment of Quarantine of Massachusetts.

${ }^{70}$ Records of the Colony of Massachusetts Bay in New England, Vol. 2, p. 280. See also Acts Relating to the Establishment of Quarantine of Massachusetts, from the Settlement of the Colony of Massachusetts Bay to the Present Time (Boston: Rockwell and Churchill, City Printers, 1881), 7 (on file with author); Order that stopt [sic] the West Indy ships at the Castle repeld [sic], May 16, 1649, *235; reprinted in Records of the Governor and Company of the Massachusetts Bay in New England, ed. Nathanial B. Shurtleff, Vol. III, 1644-1657 (1854), 168. See also Records of the Col. Of Mass. Bay in New England, Vol. 2, *280, West India Ships, May 2, 1649, reprinted in Acts Relating to the Establishment of Quarantine of Massachusetts from the Settlement of the Colony of Massachusetts Bay to the Present Time, 7 ("The Courte doth thinke meete that the order concerning the stoping of West India ships at the Castle should hereby be repealed, seeing it hath pleased God to stay the sicknes there.”) £100 in 1647 amounts to 114.46 times that amount in 2009 ; i.e., $\sim £ 11,446$. Roughly translated at the current exchange rate of 0.65 , this comes to $\$ 17,609$. For rates of inflation and exchange see http://www.measuringworth.com/datasets/ukearncpi/result.php. In terms of earnings and purchase power, however, the number increases to some $\$ 244,000$ today. Susan Wade Peabody, an early twentieth century scholar, identifies the epidemic as yellow fever. See Peabody, Historical Study of Legislation, supra note 68.

${ }^{71}$ See, e.g., Record of the Order Establishing Quarantine, Oct. 11, 1665, reprinted in Records of the Governor and Company of the Mass. Bay in New England, Vol. 4, pt. 2, 16611674 (1854), 280 (imposing quarantine on vessels in response to a typhus outbreak in London). 
The order was repealed in October 1667. Order for stopping of shipps [sic] at ye Castle repealed, October 9, 1667, reprinted in Records of the Colony of the Mass. Bay in New England, Vol. 4, pt. 2, p. 345. See also An Act for the Better Preventing of the Spreading of Infectious Sicknesses, July 18, 1699 (Massachusetts-Bay), 11 Wm. 3.

${ }^{72}$ The Massachusetts charter of 1691 expressly granted the Privy Council three years to disallow a statute. See I Poore's Charters (1877) 952. Disallowed by the Privy Council October 22, 1700. See Acts Relating to the Establishment of Quarantine of Massachusetts from the Settlement of the Colony of Massachusetts Bay to the Present Time, 9.

${ }^{73}$ Acts of the Privy Council, 1613-80, p. 841, quoted in H. E. Egerton, "The Seventeenth and Eighteenth Century Privy Council in Its Relations with the Colonies," J. Comp. Legis. \& In'l L. 7, 3d Ser., no. 1 (1925): 7.

${ }^{74}$ The creation of the Lords of Trade and Plantations (more commonly referred to as the Board of Trade) in 1696 broadly coincides with the introduction of the quarantine provision and signals particular concern about trade and relations with the colonies. See Dickerson, American Colonial Government, 1696-1765 (1912); Basye, The Lords Commissioners of Trade and Plantations, 1748-1782 (1925); Russell, The Review of American Colonial Legislation by the King in Council (1915).

${ }^{75}$ Full text or order quoted in Peabody, Historical Study of Legislation, supra note 68, p. 42.
${ }^{76}$ Ibid.
${ }^{77}$ Ibid. 
${ }^{78}$ An Act Providing in Case of Sickness, June 25, 1701, Massachusetts Bay Colony, c. 9, reprinted in Acts Relating to the Establishment of Quarantine of Massachusetts from the Settlement of the Colony of Massachusetts Bay to the Present Time, 11 [LB GETTING §§1-3].

${ }^{79}$ Ibid., c. $9, \S 4$.

${ }^{80}$ An Act to oblige all Ships and other Vessels coming from France, and other parts of the World Infected with the Plague, to perform Quarentine [sic], reprinted in Acts and Laws of Her Majesties Province of the Massachusetts Bay in New England, 1714, pp. 355-56.

${ }^{81}$ Ibid.

82 Ibid.

83 Ibid.

${ }^{84}$ Ibid.

${ }^{85}$ Ibid. (Emphasis in original.)

${ }^{86}$ Ibid.

${ }^{87}$ Ibid.

${ }^{88}$ See Peabody, Historical Study of Legislation, supra note 68, p. 3.

${ }^{89}$ Occurrence of such orders in $1702,1714,1716,1725,1738,1742$. Ibid., p. 3.

${ }^{90}$ For details on the legal framework for the founding of the colony, see A Petition of Right to Benjamin Fletcher, Captain-General and Governor in Chief in and over the Province of Pennsylvania, and country of New-Castle, \&c, reprinted in Laws of the Commonwealth of Pennsylvania, from Oct. 14, 1700 to Mar. 20, 1810, Vol. 1, 9-11.

${ }^{91}$ Act to Prevent the Coming of Sickly Vessells, \&c., *26 (preventing vessels without bills of health from coming within one mile of shore or landing passengers without license from the governor and council, or two justices of the peace, with a penalty of $£ 100$ ) (Act repealed 
January 22, 1774). An Act to oblige infected ships and other vessels coming into this province to perform quarantine, Lib. HS. Fol. 655, November 1766, reprinted in The Laws of Maryland to which are prefixed the Original Charter with an English Translation the Bill of Rights and Constitution of the State as originally adopted by the convention, with several alterations by Acts of Assembly, Vol. I, 1799, c. 25 (preventing any vessels, goods, or passengers to land before the making of an oath "that neither the small-pox, gaol fever, yellow fever, flux, or any such dangerous infectious distemper, is or hath been on board such ship or vessel on her passage, to the knowledge or belief of such captain, or other persons taking such oath respectively").

${ }^{92}$ Ibid. See also Edelman, "International Travel and Our National Quarantine System," at 29-30. (Quoting also the preamble to the act: "Whereas it hath been found, by sad experience that the coming and arriving of unhealthy vessels at the ports and towns of this province and territories, and the landing of their passengers and goods, before they have lain some time to be purified, have proved very detrimental to the health of the inhabitants of this province ...") See also Hampton, "Development of the National Maritime Quarantine System of the United States," supra note 68, p. 1246.

${ }^{93}$ Edelman, "International Travel and Our National Quarantine System.” See also Hampton, "Development of the National Maritime Quarantine System of the United States," supra note 68, p. 1246.

${ }^{94}$ An ACT, to Prevent the Spreading of Infectious Sickness, February 27, 1711, * $\{\{$ John: ?\}365-66, reprinted in The Earliest Acts and Laws of the colony of Rhode Island and Providence Plantations 1647-1719 (1977), pp. 201-2. This act appears verbatim in 1719, again, without a terminal date. See Acts and Laws of His Majesties Colony of Rhode-Island, and ProvidencePlantations in America, 1719, *\{\{John: ?\}\}65-66. 
${ }^{95}$ Ibid., *\{\{John: ?\}\}65, p. 201.

96 Ibid.

${ }^{97}$ An Act to prevent the Small Pox being brought into this Colony from the Town of Boston, \&c., August, 10, 1721, *\{\{John: ?\}\}120. The Charter Granted by His Majesty King Charles the Second, to the Colony of Rhode Island, and Providence-Plantations, in America. Newport, Rhode-Island. Printed by James Franklin, and sold at his shop near the town SchoolHouse, 1730. [2], 12, [12], [2], 210, p. 29 cm (fol.); Early American Imprints, Series 1, no. 3346 (filmed).

98 Ibid.

${ }^{99}$ Ibid., *\{\{John: ?\}\}121-22.

${ }^{100}$ An ACT to prevent the Spreading of the Small Pox and other contagious Sickness in this Colony, 1743, *274. The Charter Granted by His Majesty King Charles II, Newport, 1744, 15, [18], 308. (The charter was printed to accompany the 1745 ed. of the Acts and Laws, with which it is here reproduced.)

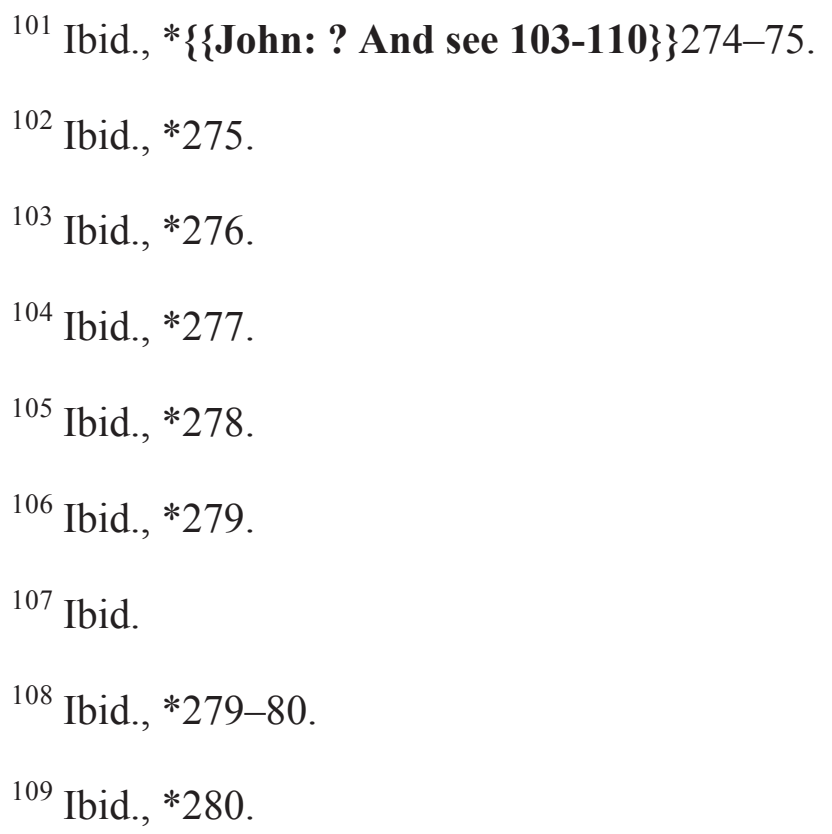


${ }^{110}$ Ibid.

${ }^{111}$ Ibid. (Emphasis in original.)

${ }^{112}$ Elizabeth Anne Fenn, Pox Americana: The Great Smallpox Epidemic of 1775-82

(2001), 273. In autumn 1777, Valley Forge became the site for general inoculation. Francis Randolph Packard, The History of Medicine in the United States (1901), 264, 283, 315.

${ }^{113}$ Fenn, Pox Americana supra note 113, p. 131.

${ }^{114}$ Quoted in ibid., 131.

${ }^{115}$ Discussed by Fenn, ibid.; see also Benjamin Franklin, “The Retort Courteous," in The Writings of Benjamin Franklin, Vol. 10, ed. Albert Henry Smyth (1907), 111.

${ }^{116}$ Fenn, ibid., 132. Robert Donkin, for instance, a British officer in New York, explicitly directed the use of smallpox as a weapon, writing, "Dip arrows in matter of smallpox and twang them at the American rebels, in order to inoculate them; This would sooner disband thee stubborn, ignorant, enthusiastic savages, than any other compulsive measures. Such is their dread and fear of that disorder!" Later in the war, General Alexander Leslie sent a letter to Lord Cornwallis, indicating his plan to distribute sick soldiers throughout the "Rebell Plantations." Ibid.

117 Ibid.

118 1776-77, c. 7.

${ }^{119}$ See, e.g., An Act permitting Inoculation for the Small-Pox to be practiced in this Colony, Colony of Rhode-Island \&c. in General Assembly, June Session, 1776.

120 The original act, An Act to oblige infected ships and other vessels coming into this province to perform quarantine, Lib. HS. Fol. 655, ch. XXV, November 1766, was to continue in force for three years. Ibid., §8. It was renewed by 1769 , c. 4; continued again in June 1773, c. 2; 
continued for seven years by February 1777, c. 17; continued until the end of the next session by 1784 , c. 83 , continued for seven years by 1785 c. 77 , and again continued to October 30,1799 by 1792, c. 77. An Act to oblige infected ships and other vessels coming into this province to perform quarantine, Lib. HS. Fol. 655, ch. XXV, November 1766, in The Laws of Maryland to which are Prefixed the Original Charter, with an English Translation, the Bill of Rights and Constitution, 1799, p. §8.

${ }^{121}$ The Constitution of Maryland, Art. 33, reprinted in The Laws of Maryland to which are prefixed the Original Charter with an English Translation the Bill of Rights and Constitution of the State as originally adopted by the convention, with several alterations by Acts of Assembly, Vol. I, 1799.

${ }^{122}$ See Ibid.

${ }^{123} \mathrm{An} \mathrm{ACT}$ to define and ascertain the powers of the governor on the subject therein mentioned. Lib. JG. No. 2 fol. 30, reprinted in Laws of Maryland to which are prefixed the original charter with an English translation, the bill of rights, and the constitution of the state, Vol. II (1800).

${ }^{124} \mathrm{An}$ ACT to appoint a health officer for the port of Baltimore-town in Baltimore county. Lib. JG. No. 2 fol. 70., reprinted in Laws of Maryland to which are prefixed the original charter with an English translation, the bill of rights, and the constitution of the state, Vol. II (1800).

${ }^{125}$ See, e.g., An Ordinance to preserve the health of the city, and to prevent the introduction of pestilential and other infectious diseases into the same, Apr. 7, 1797 (repealed by an Ordinance passed February 27, 1799); A Supplement to the ordinance, entitled "An ordinance to preserve the health of the city, and to prevent the introduction of the pestilential and other 
infectious diseases, into the same," July 17, 1797 (repealed by an Ordinance passed February 27, 1799); A Further Supplement to the ordinance entitled "An ordinance to preserve the health of the city and to prevent the introduction of the pestilential and other infectious diseases into the same," September 4, 1797 (repealed by an Ordinance passed February 27, 1799); A Further additional Supplement to the ordinance, entitled "An ordinance to preserve the health of the city and to prevent the introduction of the pestilential and other infectious diseases into the same," February 28, 2798 (repealed by an Ordinance passed February 27, 1799); A Supplement to the ordinance entitled "An ordinance to preserve the health of the city and to prevent the introduction of the pestilential and other infectious diseases into the same," July 15, 1800 (repealed by an Ordinance passed March 20,1801), reprinted in Ordinances of the Corporation of the City of Baltimore, with the Act of Incorporation and Supplement thereto prefixed, 1801, $300-317$.

${ }^{126}$ See, e.g., An Act to prevent the bringing in and spreading of infectious Distempers in this State, Passed May 4, 1784, Laws of the State of New-York, Seventh Session, 1784, ch. LVII, pp. 82-83. See also Greenleaf's Laws of New York 1, no. 117; An Act to prevent the spreading of contagious Sickness, June 22, 1797, reprinted in The Laws of the commonwealth of Massachusetts from Nov. 28, 1790 to Feb. 28, 1807, with the Constitutions of the United States of America and of the commonwealth, Vol. II, June 1807, p. 788; An ACT to prevent infectious diseases being brought into this state, and for other purposes, Jan. 24, 1797, reprinted in Laws of the State of Delaware, from the fourteenth Day of October, 1700 to the Eighteenth Day of August, 1797, Vol. II, 1354-58; A Supplement to the act, entitled, An act to prevent infectious diseases being brought into this State, and for other purposes, 1799, reprinted in Laws of the State of Delaware, from Jan. 2, 1798 to Jan. 25, 1805, Vol. III, 1816, 47-52; An Act Providing 
in Case of Sickness, 1794, Acts and Laws of the State of Connecticut in America, p. 227-31; See, e.g., An ACT to prevent infectious diseases being brought into this state, and for other purposes, Jan. 24, 1797, reprinted in Laws of the State of Delaware, from the fourteenth Day of October, 1700 to the Eighteenth Day of August, 1797, Vol. II, 1354-58; A Supplement to the act, entitled, An act to prevent infectious diseases being brought into this State, and for other purposes, 1799, reprinted in Laws of the State of Delaware, from Jan. 2, 1798 to Jan. 25, 1805, Vol. III, 1816, 47-52; Acts and Resolutions of the General Assembly of the State of SouthCarolina, passed in April, 1794, Resolution in the House of Representatives, April 30, 1794, *\{\{John: ?\}\}20; An Act reducing into one, the several Acts to oblige Vessels, coming from foreign Parts, to perform Quarantine, December 26, 1792, reprinted in A Collection of all such Acts of the General Assembly of Virginia, of a public and permanent Nature, as are now in Force (1794), 254-56.

${ }^{127}$ An Act to prevent the spreading of contagious Sickness, June 22, 1797, reprinted in The Laws of the Commonwealth of Massachusetts from Nov. 28, 1790 to Feb. 28, 1807, with the Constitutions of the United States of America and of the commonwealth, Vol. II, June 1807, p. 788.

${ }^{128}$ Ibid.

${ }^{129}$ Ibid., 789.

${ }^{130}$ Ibid.

${ }^{131}$ Ibid.

${ }^{132}$ Ibid., 789-90.

${ }^{133}$ An ACT to empower the Town of Boston to choose a Board of Health, and for removing and preventing Nuisances, June 20,1799, reprinted in The Perpetual Laws of the 
Commonwealth of Massachusetts, from the Establishment of its of its Constitution in the year 1780, to the end of the year 1800, Vol. III, containing the Laws from January 1799 to November 1800, March 1801, pp. 41-50.

${ }^{134}$ Ibid. (Emphasis in original.)

${ }^{135}$ Ibid., $\S 8$.

${ }^{136}$ An Act Providing in Case of Sickness, 1794, Acts and Laws of the State of Connecticut in America, pp. 227-31.

${ }^{137}$ Ibid., 228.

${ }^{138}$ Ibid., 229.

${ }^{139}$ Ibid.

${ }^{140}$ Ibid., 230.

${ }^{141}$ Ibid., 231. ("[W]henever any Person shall be brought to Trial for Breach of this Act, in communicating or receiving the Small-Pox, aiding or assisting therein, such Person shall be deemed and adjudged guilty thereof, although the complainant shall not be able to produce any other Proof than to render it probable.") The statute allowed, however, for the accused to counter the accusation by swearing to the court that he or she did not voluntarily, directly, or indirectly give or receive the infection. Ibid.

${ }^{142}$ See, e.g., A Supplement to the act, entitled, An act to prevent infectious diseases being brought into this State, and for other purposes, 1799, reprinted in Laws of the State of Delaware, from Jan. 2, 1798 to Jan. 25, 1805, Vol. III, 1816, pp. 47-52 (granting the local authorities "with full power and authority, to suspend altogether the intercourse by land, between any cities, towns or places in the United States, or elsewhere, during the existence or prevalence of any infectious or contagious disorder, and the said borough, town, or other part or district in this State ..."). 
1431 Stat. 353 (1794), 2 U.S.C. $\$ 27$ (1958).

${ }^{144}$ An Act Relative to Quarantine, May 27, 1796, ch. 31, 1 Stat. 474 (repealed 1799) 1789-1799. See also 6 Annals of Congress, 2916 1796-1797 ("Be it enacted, \&c., That the President of the United States be and he is hereby authorized to direct the revenue officers and the officers commanding forts and revenue cutters, to aid in the execution of quarantine, and also in the execution of the health laws of the States respectively, in such manner as may to him appear necessary"). For discussion of the yellow fever epidemic raging at the time, see J. H. Powell, Bring out Your Dead: The Great Plague of Yellow Fever in Philadelphia in 1793 (1949). 145 Act of May 27, 1796, ch. 31, 1 Stat. 474 (repealed 1799). See also 43 Am. L. Rev 382 at 384 .

${ }^{146}$ See Annals of Congress, 4th Cong., 1st Session, col. 87, May, 13, 1796 (committing “An act relative to quarantine" to Mssrs. Rutherfurd, Bingham, and Langdon, to consider and report to the Senate); The Debates and Proceedings of the Congress of the United States; with an Appendix containing Important State Papers and Public Documents, Fourth Congress_-First Session, Dec. 7, 1795-June 1, 1796 (1855), 1347-1360. See also Goodman et al., Law in Public Health Practice, supra note 68 (noting the tenor of the debates).

${ }^{147}$ Statement of Mr. Milledge, The Debates and Proceedings of the Congress of the United States; with an Appendix containing Important State Papers and Public Documents, Fourth Congress-First Session, December 7, 1795-June 1, 1796 (1855), May 12, 1796, 135051 ("spoke ... of the power of regulating quarantine being in the State Governments").

${ }^{148}$ See, e.g., Statement of Mr. W. Lyman, ibid., 1352 (who "thought the individual States had the sole control over the regulations of quarantine. It was by no means a commercial regulation, but a regulation which respected the health of our fellow-citizens"); Statement of Mr. 
Lyman, ibid., May 12, 1796, 1354 (“Quarantine was not a commercial regulation, it was a regulation for the preservation of health. If commerce was incidentally affected, it ought so to be, when the object was the preservation of health and life. The United States, it was true, could prevent the importation of any goods, whether infected or not, but it did not thence follow that they could permit the landing of infectious goods contrary to the laws of any State. The several States possessed the sole power over this subject. They were the best judges of the due exercise of it"); Statement of Mr. Page, ibid., May 12, 1796, 1357 ("the right of the people to preserve their health ... was one of the first rights of Nature"). See also Statement of Mr. Gallatin, ibid., May 12, 1796, 1353 (“'[T]he regulation of quarantine had nothing to do with commerce. It was a regulation of internal police. It was to preserve the health of a certain place, by preventing the introduction of pestilential diseases, by preventing persons coming from countries where they were prevalent. Whether such persons came by land or by water, whether for commerce or for pleasure, was of no importance. They were all matters of police"). See also Statement of Mr. Lyman, ibid., May 12, 1796, 1354 ("The right to preserve health and life was inalienable. The bill was not only unnecessary and improper, but it was an injudicious interference with the internal police of the States"); Statement of Mr. Holland, ibid., May 12, 1796, 1358 (noting "The Constitution being silent with respect to health laws, he supposed the passing of them was left to the States themselves"); Statement of Mr. Brent, ibid., May 12, 1796, 1358 (suggesting that "the Constitution did not authorize" such federal interference with state police powers).

${ }^{149}$ Statement of Mr. Milledge, ibid., May 12, 1796, 1351.

${ }^{150}$ Ibid.

${ }^{151}$ Statement of Mr. Giles, ibid., May 11, 1796, 1348. 
${ }^{152}$ Statement of Mr. Swanwick, ibid., May 12, 1796, 1350. ("the time during which quarantine should be performed, and at what particular place, which would certainly be best determined by the State Governments. ... Indeed, most of them having already fixed on places for the purpose, and erected suitable buildings for the sick, for purifying goods, \&c. It was said, the right of regulating quarantine did not reside in the State Governments; he believed it did, and that the individual States had conceived so, was evident from the expense which some of them had been at in erecting buildings, \&c., for the purpose").

${ }^{153}$ See, e.g., Statement of Mr. S. Smith, ibid., May 11, 1796, 1348. ("the performing of quarantine was in the direction of the General Government: it was a commercial regulation"); Statement of Mr. Bourne, ibid., May 12, 1796, 1350; Statement of Mr. Sitgreaves, ibid., May 12, 1796,1350 (" $[\mathrm{T}]$ he strongest and best reason for a law, such as the one proposed, is, that it is a matter of very serious doubt whether, upon this subject, the States had any authority at all, and whether all such power is not vested by the Constitution in the congress, under their general authority to regulate commerce and navigation"); Mr. Hillhouse, ibid., (1855), May 12, 1796, 1352-1353 ("Gentlemen might as well say that the individual States had the power of prohibiting commerce as of regulating quarantine: because, if they had the power to stop a vessel for one month, they might stop it for twelve months. This might interfere with regulations respecting our trade, and break our Treaties").

${ }^{154}$ See, e.g., Statement of Mr. Smith, ibid., May 11, 1796, 1348 (“[States] could not command the officer of a fort to use force to prevent a vessel from entering their port. The authority over him was in the General Government"); Statement of Mr. Smith, ibid., May 11, 1796, 1348 ("[T] vessels from coming into their ports"); Statement of Mr. Sitgreaves, ibid., May 12, 1796, 1350 
("It was true, the State of Pennsylvania had made some regulations on the subject of quarantine; but, without the aid of the United States, they could not carry them into effect. They may direct, by their Governor and board of Health, quarantines to be performed, but they could not force any vessels to observe their directions, without the aid of the General Government").

${ }^{155}$ Elizabeth Fee, "Public Health and the State: The United States," in The History of Public Health and the Modern State, ed. Dorothy Porter (1994), 224, 233.

${ }^{156}$ An Act Respecting Quarantines and Health Laws, Fifth Congress, Sess. III, ch. 12, 1799, February 25, 1799, 619-21, §1. See also 1 Stat. 619 (1799), 42 U.S.C. $\S 97$ (1958). For discussion of this statute, see Maxey, "Federal Quarantine Law," Pol. Sci. Q. 23, no. 4 (December 1908): 617-18.

${ }^{157}$ An Act Respecting Quarantine and Health Laws, 1 Stat. 619 (1799), 42 U.S.C. $\S 97$ (1958), §2.

${ }^{158}$ See Debates and Proceedings of the Congress of the United States, Fifth Congress, May 15, 1797-March 3, 1799 (1851), 2792-95.

${ }^{159}$ Act of February 25, 1799, ch. 12, I Stat. 619.

${ }^{160}$ Act of February 25, 1799, ch. 12, I stat. 620, §3.

${ }^{161}$ Hugh S. Cumming, "The United States Quarantine System during the Past Fifty Years," in A Half Century of Public Health (1921), 120-21.

${ }^{162}$ Gibbons v. Ogden, 22 U.S. 1, 205-6 (9 Wheat) (1824).

${ }^{163}$ Opinions of the Attorneys-General of the United States, 1829, 2, 263-66.

${ }^{164}$ See, e.g., Mitchell v. City of Rockland, 45 Me. 496 (1858). 
${ }^{165}$ By 1873 , more than thirty boards of health had formed. Chapin, "History of State and Municipal Control of Disease," supra note 66, pp. 137-38. For further discussion see Donohue, "Biodefense and Constitutional Constraints," supra note 60.

${ }^{166}$ See, e.g., American State Papers, Documents, Legislative and Executive, of the Congress of the United States, March 3, 1789-March 3, 1815, Vol. VII (1832), 532 ("The recent accounts of the severe quarantine of 120 days, imposed upon American vessels, in some of the principal ports of Spain, must fill every friend of our commerce with regret. It amounts to an almost total prohibition of our trade with those cities; and is viewed by your committee, as arising from the false alarms and unfounded suggestions among our own citizens. In order to prevent these alarming evils, it is necessary to form our health laws upon more scientific principles, and to regulate our commercial intercourse upon maxims more accordant with domestic neatness and economy"); and John BOOKER, MARITIME Quarantine: The British ExPerience C 1650-1900 (2007); J.L. Brand, Doctors AND the State: The British Medical Profession and Government Action in Public Health, 1870-1912 (1965), p. 259, fns. 3943 (citing Privy Council Orders specifically targeting vessels from the United States). See also discussion in Donohue, "Biodefense and Constitutional Constraints," supra note 60.

${ }^{167}$ See, e.g., Booker, supra note 168, p. 368.

${ }^{168}$ Maxey, "Federal Quarantine Law," 617-18.

${ }^{169}$ American State Papers, Documents, Legislative and Executive, of the Congress of the United States, March 3, 1789-March 3, 1815, Vol. VII (1832), 532.

${ }^{170}$ Ibid., 532.

171 Ibid. 
${ }^{172}$ Michael Les Benedict, "Contagion and the Constitution: Quarantine Agitatio from 1869 to 1866," J. of the History of Medicine (April 1970): 178.

173 Ibid.

${ }^{174}$ National Quarantine and Sanitary Convention, Proceedings and debates of the fourth national quarantine and sanitary convention, June 14, 15, and 16, 1860 (Boston, 1860), 170.

${ }^{175}$ See, e.g., National Quarantine and Sanitary Convention, Proceedings and debates of the second national quarantine and sanitary convention, held in the city of Baltimore, May 3, 1858, available at http://query.nytimes.com/mem/archivefree/pdf?res=F30D1EFA3E581B7493C1A9178ED85F4C8584F9; National Quarantine and Sanitary Convention, Proceedings and debates of the third national quarantine and sanitary convention, held in the city of New York, April 27, 28, 29, and 30, 1839 (New York, 1859); National Quarantine and Sanitary Convention, Proceedings and debates of the Fourth National Quarantine and Sanitary convention, June 14, 15, and 16, 1860 (Boston, 1860).

${ }^{176}$ Jeffery K. Smart, “Chemical and Biological Warfare Research and Development during the Civil War," U.S. Army Soldier and Biological Chemical Command, p. 5, available at http://www.wood.army.mil/ccmuseum/ccmuseum/Library/Civil_War_CBW.pdf .

${ }^{177}$ See, e.g., Ibid.; Albert Clarke, “The Youngest Officer in the War," in Stories of Our Soldiers (1893), 229; J. D. Haines, "Did a Confederate Doctor Engage in a Primitive Form of Biological Warfare? The Northern Press Thought So," America's Civil War 12, no. 4 (September 1999): 12, 16, and 20; Andrew G. Robertson and Laura J. Robertson, "From Asps to Allegations: Biological Warfare in History,” Military Medicine 160, no. 8 (August 1995): 369-70.

${ }^{178}$ War Department General Orders No. 100.

${ }^{179}$ Les Benedict, supra note 173, p. 181. 
${ }^{180}$ Cong. Globe, 39 C., 1 S., p. 1201.

${ }^{181}$ Ibid., 2444-45.

182 Ibid., 2445.

${ }^{183}$ Les Benedict, supra note 173, p. 188.

${ }^{184}$ Ibid., 189.

${ }^{185}$ Cong. Globe, 39 C., 1 S., p. 2521.

${ }^{186}$ In 1879 marine hospitals were folded into a national Marine Hospital Service.

Sciarrino, "Part III: Epidemics,” supra note 57, pp. 432-33; and Cumming, "The United States Quarantine System,” supra note 163, p. 120. The surgeon general began calling for a uniform federal system. Comments by Surgeon General Woodworth at the International Medical Congress in Philadelphia, 1876, discussed in ibid, p. 121. Discoveries by Louis Pasteur, Ferdinand Cohn, and Robert Koch led to the field of microbiology, entrenching the germ theory of disease. Colum. L. Rev. 93 (1833, 1865). The germ theory of disease took hold. Frederick P. Gorham, "The History of Bacteriology and Its Contribution to Public Health Work," in A Half Century of Public Health (1920), 69. For other influences of the germ theory of contagion on calls for quarantine law, see "Report of the committee of the college of Physicians of Philadelphia: Appointed to Investigate the Efficiency of Our Quarantine Arrangements for the Exclusion of Cholera and Other Epidemic Diseases, October 28, 1887," p. 1 (writing, "The acceptance of the germ theory of infectious and contagious diseases, or the probability at least of its truth, places in a new light the management of quarantine for detention and disinfection of vessels and their passengers"). See also Cumming, "The United States Quarantine System," supra note 163, p. 120. 
${ }^{187}$ An Act to prevent the introduction of contagious or infectious diseases into the United States, April 29, 1878, ch. 66, 20 Stat 37.
188 Ibid.
189 Ibid.
${ }^{190}$ Ibid., 2 .

${ }^{191}$ Cumming, "The United States Quarantine System,” supra note 163, p. 121. The

following year, Congress repealed the sections of the statute empowering the Marine Hospital Service to make rules and regulations independent of state boards. An act to prevent the introduction of infectious or contagious diseases into the United States, and to establish a national board of health, March 3, 1879, ch. 202, 20 Stat 484, §10. See also Act of July 1, 1879, ch. 61, 21 Stat. L. 47 (amending the 1879 act and designating a disbursing agent). In a twist of sunset standards, the repeal (not the act) was set to expire after four years, at which time the original legislation went back into force. An act to prevent the introduction of infectious or contagious diseases into the United States, and to establish a national board of health, March 3, 1879, ch. 202, 20 Stat 484, §10; “Government Officers Anxious: The Power of the Federal Authorities in Quarantine Matters," New York Times, September 1, 1989, available at http://query.nytimes.com/mem/archivefree/pdf?res=F60C1EF83C5F1B738DDDA80894D1405B8285F0D3.

${ }^{192}$ An act to prevent the introduction of infectious or contagious diseases into the United States, and to establish a national board of health, March 3, 1879, ch. 202, 20 Stat 484.

193 “Government Officers Anxious: The Power of the Federal Authorities in Quarantine Matters," New York Times, September 1, 1892. 
${ }^{194}$ See, e.g., Cumming, “The United States Quarantine System,” supra note 163, p. 122

(highlighting the role of the MHS in stemming an 1882 yellow fever epidemic in Texas).

195 "Report of the committee of the college of Physicians of Philadelphia: Appointed to Investigate the Efficiency of Our Quarantine Arrangements for the Exclusion of Cholera and Other Epidemic Diseases," 44\{\{Author: Page 44? Pub. info.?\}\} (October 28, 1887), p. $3\{\{$ Author: Please confirm.\}\}.

${ }^{196}$ Ibid., 16 (writing, "The ability of the National Government, by an existing act of Congress, to come to the aid of local quarantine authorities in answer to the appeal of the Executive of any State in time of grave danger, implies a function of very narrow scope and uncertain application. Appeals of this kind are apt to be deferred until the emergency is extreme, and the aid obtained from the Government is, therefore, likely to be rendered too late to accomplish its most important purpose, namely, the prevention of an invasion").

${ }^{197}$ Ibid., 3. See also p. 19, writing, "Municipalities are selfish, and knowing that with the trader quarantine is not a favorite institution, and that it is his tendency to sail into that port where the quarantine is most lax, they are assailed with a sore temptation to wink at the neglect of proper precautions, if, by so doing, they may circumvent a possible commercial rival."

${ }^{198}$ See, e.g., ibid., 13 (discussing the failure of the exterior ports to act with dispatch to prevent the 1873 cholera epidemic, which ended up hurting Ohio, Minnesota, and the Dakotas the most); ibid., 18 (discussing failure of Florida port to prevent the 1887 yellow fever outbreak).

$$
\begin{aligned}
& { }^{199} \text { Ibid., 5-6. } \\
& { }^{200} \text { Ibid., } 20 . \\
& { }^{201} \text { See, e.g., "Report of the committee of the college of Physicians of Philadelphia: }
\end{aligned}
$$
Appointed to Investigate the Efficiency of Our Quarantine Arrangements for the Exclusion of 
Cholera and Other Epidemic Diseases, October 28, 1887," p. 44 (writing, "We know that there are legislative difficulties in the way; that quarantine partaking of the nature of police regulation, its exercise, it may be claimed, belongs to the local authorities. Yet, even if it be conceded to be a police regulation, its scope is not local, but extends over the whole country, and it would seem, in justice, that it should be exercised and paid for by the whole country"); Col. J. C. Clark, VicePresident Mobile \& Ohio Railroad, "Quarantine Regulations," in Proceedings of the Quarantine Conference Held in Montgomery, Alabama, March 5-7, 1889, Appendix III, pp. $69-70$ (writing, "The national government should take charge of and maintain a rigid maritime quarantine, and locate such quarantine stations at such points on the sea-coast and on navigable rivers, at proper points, so as to prevent the introduction of yellow fever or any other contagious or infectious disease into any state or territory of the United States, leaving to the state authorities, the power to deal with these matters in the states, outside of maritime quarantine"); "Resolutions offered by Mr. B. R. Foreman, of New Orleans," in Proceedings of the Quarantine Conference Held in Montgomery, Alabama, March 5-7, 1889, Appendix V, p. 86.

${ }^{202}$ Act 69 of the Legislature of Louisiana of 1882, §1.

${ }^{203}$ Morgan's Steamship Company v. Louisiana Board of Health, 118 U.S. 455 (1886). U.S. Const., Art I, §10(2) states, "No State shall, without the Consent of the Congress, lay any Imposts or Duties on Imports or Exports, except what may be absolutely necessary for executing its inspection Laws: and the net Produce of all Duties and Imposts, laid by any State on Imports or Exports, shall be for the Use of the Treasury of the United States; and all such Laws shall be subject to the Revision and control of the Congress." Art. I §10(3) states, "No State shall, without the Consent of the Congress, lay any duty of Tonnage.” Article I, §8(3) gives congress power to regulate commerce ([The Congress shall have Power] To regulate Commerce with 
foreign Nations, and among the several States, and with the Indian Tribes.” Art. I, §9(6) declares, "No Preference shall be given by any Regulation of Commerce or Revenue to the Ports of one State over those of another; nor shall Vessels bound to, or from, one State, be obliged to enter, clear, or pay Duties in another."

${ }^{204}$ Ibid\{\{Author: Which reference do you mean here?\}\}., p. 464.

${ }^{205}$ An Act to Perfect the Quarantine Service of the United States, August 1, 1888, ch. 727, 25 Stat. L. 355; An act to Prevent the Introduction of Contagious Diseases from one state to another and for the punishment of certain offenses, [also known as the "Epidemic Diseases Act”], March 27, 1890, ch. 51, 26 Stat. L. 31; Immigration Act of March 13, 1891; An Act Granting Additional quarantine Powers and Imposing Additional Duties upon the MarineHospital Service, February 15, 1893, ch. 114, 27 Stat. L. 449, repealing An act to prevent the introduction of infectious or contagious diseases into the United States, and to establish a national board of health, March 3, 1879.

${ }^{206}$ An act to Prevent the Introduction of Contagious Diseases from one state to another and for the punishment of certain offenses, March 27, 1890, ch. 51, 26 Stat. L. 31, §1.

${ }^{207}$ Ibid.

${ }^{208}$ Ibid.

${ }^{209}$ An Act Granting Additional quarantine Powers and Imposing Additional Duties upon the Marine-Hospital Service, February 15, 1893, ch. 114, 27 Stat. L. 449, repealing An act to prevent the introduction of infectious or contagious diseases into the United States, and to establish a national board of health, March 3, 1879.

${ }^{210}$ Ibid., at $\S 3$.

${ }^{211}$ Ibid., at $\S 4794$. 
212 Ibid., at $\S 6$.

${ }^{213}$ Ibid., at $\$ 7$. It is not clear how often this power was used. By 1921, however, the authority was considered to be based on unsound science. See Cumming, "The United States Quarantine System," supra note 163, p. 122 ("In light of modern knowledge of the spread of disease, this radical measure is no longer deemed necessary, since the application of rational preventive measures provides adequate safeguards without material interference with commerce or travel").

${ }^{214}$ An Act Granting Additional quarantine Powers and Imposing Additional Duties upon the Marine-Hospital Service, February 15, 1893, §8.

${ }^{215}$ Compagnie Francaise de Navigation a Vapeur v. Louisiana State Bd. of Health, 186 U.S. 380 (1902).

${ }^{216}$ Ibid., 388.

${ }^{217}$ Ibid., 387. See also Asbell v. Kansas, 209 U.S. 251 (1908).

218 Jacobson v. Massachusetts, 197 U.S. 11, 27 (1905).

${ }^{219}$ Wendy E. Parmet et al., "Individual Rights versus the Public’s Health-100 years after Jacobson v. Massachusetts," New England J. Med. 352, no. 652 (2005).

${ }^{220}$ See, e.g., Wong Chow v. Transatlantic Fire Ins. Co., 13 Haw. 160, 161 (1900) (upholding quarantine in Honolulu). Crayton v. Larabee, 110 N. Rep. 355, 220 N.Y. 493 (N.Y. Ct. of App. 1917) (writing in relation to the quarantine of a woman suspected of having been exposed to smallpox, "The police power defines precise definition and rigid delimitation. We hold here that the ordinance was authorized, was legally adopted, was a reasonable and valid health regulation under the police power of the state, vesting in the health officer a stated 
discretionary power, which, if lawfully exercised, protected those exercising it against the consequent damages to person or property").

${ }^{221}$ The Minnesota Rate Cases, 230 U.S. 352, 406 (1913).

${ }^{222}$ Edelman, "International Travel and Our National Quarantine System," 35.

${ }^{223}$ Colum. L. Rev. 93 (1833, 1865).

${ }^{224}$ Chapin, "History of State and Municipal Control of Disease," supra note 66, p. 132;

Cumming, "The United States Quarantine System," supra note 163, p. 131.

${ }^{225}$ Cumming, supra note 163 pp. 123-24.

${ }^{226}$ Codified as amended at 42 U.S.C. $\S \S 264-72$.

${ }^{227}$ Robert T. Stafford Disaster Relief and Emergency Assistance Act (PL 100-707), amending the Disaster Relief Act of 1974, PL 93-288. Current codified provisions, as further amended, at 42 U.S.C. $§ 5121-5207$ (2007).

${ }^{228} 42$ U.S.C. $\S 264(\mathrm{a})$; and 42 C.F.R. $\S \S 70-71$. See also 21 CFR $\S 1240.3$ et seq. In 1953 the Eisenhower administration launched the Department of Health, Education and Welfare (HEW) under the executive's then-existing authority to form new bureaucratic entities absent legislative veto. President Dwight D. Eisenhower, Reorganization Plan No. 1 of 1953, Transmitted to Congress March 12, 1953, available at http://www.presidency.ucsb.edu. In 1980 HEW became the Department of Health and Human Services. 20 U.S.C. 3508 (Redesignation of Department of Health, Education, and Welfare).

${ }^{229}$ SARS (April 4, 2003), and pandemic influenza (April 2005).

${ }^{230} 42$ U.S.C. $\$ 264(d)$. "Qualifying stage” means disease is in communicable stage, or is in a precommunicable state, if the disease would likely cause a public health emergency if transmitted to other individuals. 42 U.S.C. §264(d)(2). 
${ }^{231} 1944$ Public Health Services Act, 58 Stat. 682, §361; codified at 42 U.S.C. $§ 264(d)$. In 2000 federal regulations delegated this authority to the director of the CDC, with the actual determination made by the CDC's Division of Global Migration and Quarantine. 65 FR 49906; and 42 C.F.R. 70.2. See also 21 CFR $\$ 5.10$ et seq.

23242 C.F.R. 70.3.

${ }^{233}$ See 42 C.F.R. §71; 42 U.S.C. $\$ 265$ (stating, "Whenever the Surgeon General determines that by reason of the existence of any communicable disease in a foreign country there is serious danger of the introduction of such disease into the United States, and that this danger is so increased by the introduction of persons or property from such country that a suspension of the right to introduce such persons and property is required in the interest of the public health, the Surgeon General, in accordance with regulations approved by the President, shall have the power to prohibit, in whole or in part, the introduction of persons and property from such countries or places as he shall designate in order to avert such danger, and for such period of time as he may deem necessary for such purpose").

${ }^{234}$ July 1, 1944, c. 373, Title III, §363, 58 Stat. 704; June 12, 2002, Pub.L. 107-88, Title I, §142(a)(3), (b)(2), 116 Stat. 626, 627.) 42 U.S.C. §266. Special Quarantine Powers in Times of War (stating, "To protect the military and naval forces and war workers of the United States, in time of war, against any communicable disease specified in Executive orders as provided in subsection (b) of section 264 of this title, the Secretary, in consultation with the Surgeon General, is authorized to provide by regulations for the apprehension and examination, in time of war, of any individual reasonably believed (1) to be infected with such disease and (2) to be a probable source of infection to members of the armed forces of the United States or to individuals engaged in the production or transportation of arms, munitions, ships, food, clothing, 
or other supplies for the armed forces. Such regulations may provide that if upon examination any such individual is found to be so infected, he may be detained for such time and in such manner as may be reasonably necessary").

${ }^{235} 42$ U.S.C. $\$ 267$ (stating “[T]he Surgeon General shall control, direct, and manage all United States quarantine stations, grounds, and anchorages, designate their boundaries, and designate the quarantine officers to be in charge thereof. With the approval of the President he shall from time to time select suitable sites for and establish such additional stations, grounds, and anchorages in the States and possessions of the United States as in his judgment are necessary to prevent the introduction of communicable diseases into the States and possessions of the United States").

${ }^{236} 42$ U.S.C. \$268(a) (stating, “Any consular or medical officer of the United States, designated for such purpose by the Secretary, shall make reports to the Surgeon General, on such forms and at such intervals as the Surgeon General may prescribe, of the health conditions at the port or place at which such officer is stationed").

${ }^{237} 42$ U.S.C. $\S \S 269-70$.

${ }^{238} 42$ U.S.C. $\$ 271$.

${ }^{239} 28$ U.S.C.A. $\$ 1331$.

${ }^{240}$ Robert T. Stafford Disaster Relief and Emergency Assistance Act, 42 U.S.C. §51215206 (2000). The Stafford Act (Pub. L. 100-707) is a 1988 amended version of the Disaster Relief Act of 1974 (Pub. L. 93-288).

${ }^{241}$ Disaster Mitigation Act of 2000, 42 U.S.C. $§ 68$ (Pub. L. 106-390) (2000) (also called DMA2K); "Disaster Relief-The Public Health and Welfare." 
${ }^{242}\{402\}\{\{$ Author: brackets?\}\} 42 U.S.C. 5170a. Specifically, the statute empowers the president to (1) direct any federal agency, with or without reimbursement, to utilize its authorities and the resources granted to it under federal law (including personnel, equipment, supplies, facilities, and managerial, technical, and advisory services) in support of state and local assistance efforts; (2) coordinate all disaster relief assistance (including voluntary assistance) provided by federal agencies, private organizations, and state and local governments; (3) provide technical and advisory assistance to affected state and local governments for- $-(\mathrm{A})$ the performance of essential community services; (B) issuance of warnings of risks and hazards; (C) public health and safety information, including dissemination of such information; (D) provision of health and safety measures; and (E) management, control, and reduction of immediate threats to public health and safety; and (4) assist state and local governments in the distribution of medicine, food, and other consumable supplies, and emergency assistance.

${ }^{243} 42$ U.S.C. $\S 5170(a)(3)(D)$. According to FEMA Regulations, when an "incident occurs or threatens to occur in a State" that would not qualify as a major disaster, a governor may request that the President declare an 'emergency," defined as "any occasion or instance, for which, in the determination of the President, [f]ederal assistance is needed to supplement State and local efforts and capabilities to save lives and to protect property and public health and safety. ...”CFR §206.2. Once these conditions are met, the FEMA associate or regional director “may provide assistance," including directing "any federal agency, with or without reimbursement, to utilize its authorities and the resources granted to it under federal law (including personnel, equipment, supplies, facilities, and managerial, technical and advisory services) in support of state and local emergency assistance efforts to save lives, protect property and public health and safety.” CFR §206.6. See also Jason W. Sapsin, Center for Law and the 
Public's Health at Georgetown and Johns Hopkins University, “Overview of Federal and State Quarantine Authority," p. 4 (2002), available at http://www.publichealthlaw.net/Resources/REsourcesPDFs/2proprietary.pdf.

${ }^{244}$ See 42 U.S.C. $§ \S 5191-93$. See also Alan Cohn, Disaster Preparedness\{\{Author: Where can this be found?\}\} text.

24542 U.S.C. $\$ 5191(b)$.

${ }^{246}$ Federal Register, Vol. 70, No. 229, Nov. 30, 2005, pp. $71892-71948$ (proposed amendments to 42 CFR Parts 71 and 71, Control of Communicable Diseases).

${ }^{247}$ Federal Register, Vol. 77, No. 247 (Dec. 26, 2012), pp. 75885-75891 (proposing Direct Final Rule); and Federal Register Vol. 78, No. 37, Feb. 25, 2013, p. 12622 (adopting Direct Final Rule).

${ }^{248}$ U.S. Const., 5th Amend; and Art. I(9)(2). For a discussion of the impact of quarantine law on these provisions see, e.g., Gostin, Public Health Law, 205-6 (2000); Paula Mindes, “Tuberculosis Quarantine: A Review of Legal Issues in Ohio and Other States," J. of L. and Health 10, no. 403 (1995-96); Wendy E. Parmet, "Legal Power and Legal Rights_-Isolation and Quarantine in the Case of Drug-Resistant Tuberculosis," N. Engl. J. Med. \{\{Author: Volume no.?\}\}(2007): 357 .

${ }^{249}$ The question here turns on what would be considered the least restrictive alternative. See discussion in Parmet, "Legal Power and Legal Rights." But see In re Washington, 716 N. W.2d 176, 292 Wis.2d 258, 2006 WI App 99 (Wis. App. 2006) (upholding the forcible detention of woman living in a homeless shelter, found to have pulmonary tuberculosis). 
${ }^{250}$ See, e.g., Miller v. Campbell Cty., 722 F. Supp. 687 (D.Who. 1989) (holding that a temporary forced evacuation from someone's home does not count as a taking for purposes of 42 U.S.C. $§ 1983)$.

251 "National Security Strategy of the United States of America," supra note 3, pp. 8, 18. ${ }^{252}$ U.S. Const. Art. II(2)(1).

${ }^{253}$ U.S. Const., Art. I(8)(11), (12).

${ }^{254}$ U.S. Const., Art. I(8)(15).

${ }^{255}$ Youngstown Sheet \& Tube Co. v. Sawyer, 343 U.S. 579 (1952).

256 Ibid.

25750 U.S.C. $1541-48$.

${ }^{258}$ Ibid.

${ }^{259}$ See Nixon veto, November 7, 1973. See also Phil Bobbitt, "War Powers: An Essay on John Hart Ely's War and Responsibility: Constitutional Lessons of Vietnam and Its Aftermath," Michigan Law Quarterly 92, no. 6 (May 1994).

${ }^{260}$ But note that the Obama administration has not challenged the War Powers Resolution specifically on these grounds.

${ }^{261}$ See, e.g., Dellums v. Bush.

${ }^{262}$ Prize Cases (1863), 67 U.S. 635.

263 Ibid.

${ }^{264}$ Emancipation Proclamation, January 1, 1863; U.S. Navy General Order no. 4, January $14,1863$. 
${ }^{265}$ Authorization for Use of Military Force against Iraq Resolution of 1991, H.R.J. Res.

77; Authorization for Use of Military Force against Terrorists, Pub. L. No. 107-40; Authorization for Use of Military Force against Iraq Resolution of 2002, Pub. L. No. 107-243.

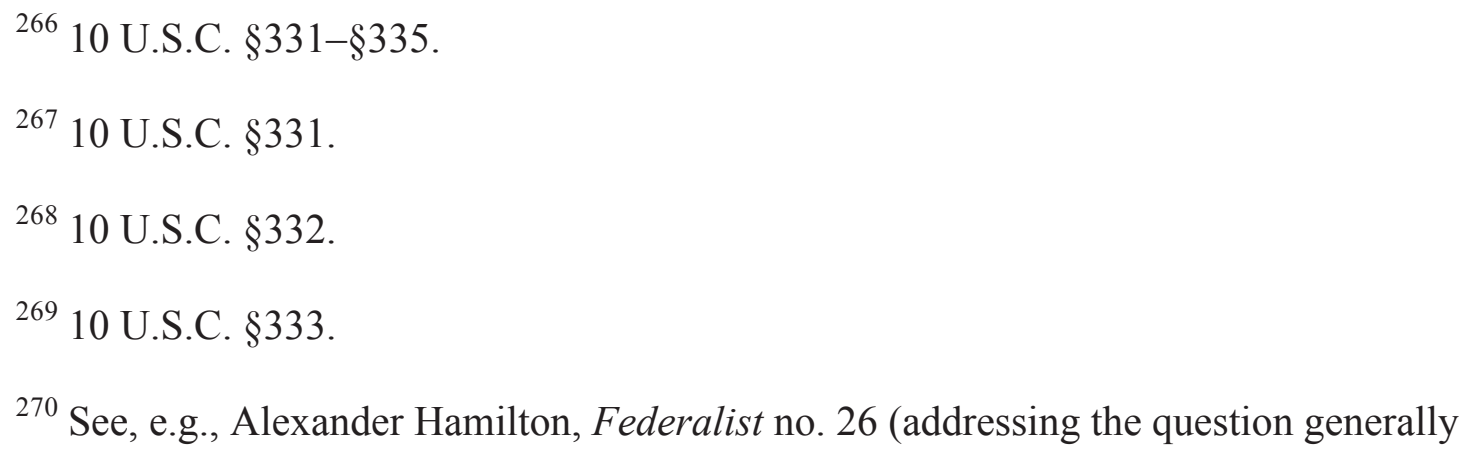


${ }^{275}$ But see Notes of the Secret Debates of the Federal Convention of 1787, Taken by the Late Hon Robert Yates, Chief Justice of the State of New York, and One of the Delegates from That State to the Said Convention, June 7, 1787, available at http://avalon.law.yale.edu/18th_century/yates.asp. (Mr. Wilson: "The State governments ought to be preserved - the freedom of the people and their internal good police depends on their existence in full vigor - but such a government can only answer local purposes - That it is not possible a general government, as despotic as even that of the Roman emperors, could be adequate to the government of the whole without this distinction. He hoped that the national government would be independent of State governments, in order to make it vigorous, and therefore moved that the above resolution be postponed, and that the convention in its room adopt the following resolve: That the second branch of the national legislature be chosen by districts, to be formed for that purpose"; Mr. Martin: "A general government may operate on individuals in cases of general concern, and still be federal. This distinction is with the States, as States, represented by the people of those States. States will take care of their internal police and local concerns. The general government has no interest but the protection of the whole.") See also Barnett, "The Proper Scope of the Police Power," supra note 275.

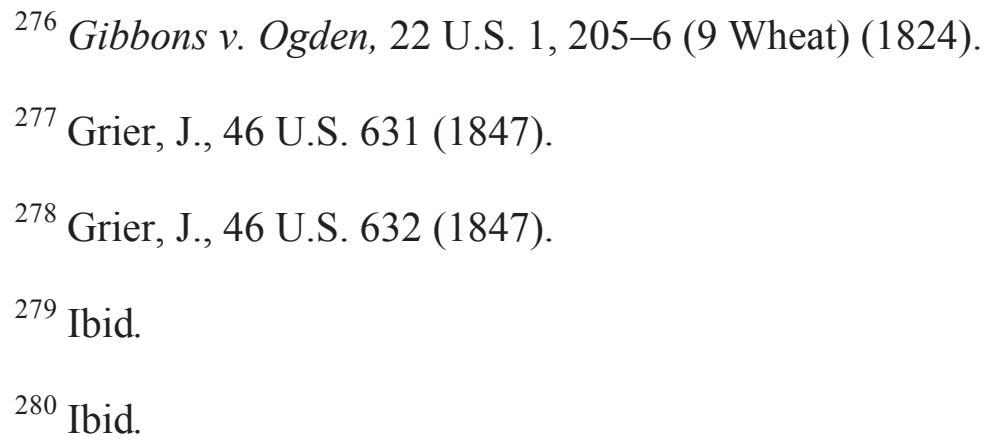


${ }^{281}$ Thomas Cooley, The General Principles of Constitutional Law in the United States of America, boston: Little, Brown, and company, 1898, p. 584. See also remarks of Grier, J. in License Cases, 5 How. 632; Meeker v. Van Rensselaer, 15 Wend. 397.

${ }^{282}$ Ibid.

${ }^{283}$ Christopher G. Tiedeman, A Treatise on the Limitations of the Police Power in the United States (1886), 4-5, citing Thorpe v. Rutland R.R., 27 Vt. 140, 149-50 (1854).

${ }^{284}$ U.S. v. Shinnick, 219 F. Supp. 789 (E.D.N.Y. 1963).

${ }^{285}$ U.S. Const. art. I, §8, cl. 18.

${ }^{286}$ The court had previously determined that the Due Process Clause does not prevent the indefinite detention of mentally ill individuals considered likely to commit "predatory acts of sexual violence." Kansas v. Hendricks, 521 US 346, 352 (1997).

${ }^{287}$ Comstock, 130 S.Ct. at $1958-64$.

${ }^{288}$ Ibid., 1956.

${ }^{289}$ Ibid., 1966 (Kennedy, J., concurring).

${ }^{290}$ Ibid., 1968 (Kennedy, J., concurring).

${ }^{291}$ Ibid., 1970 (Alito, J., concurring).

292 Ibid., 1974 (Thomas, J., dissenting) (quoting U.S. Const. art I, §8, cl. 18).

${ }^{293}$ Ibid., 1973 (Thomas, J., dissenting).

${ }^{294}$ Ibid., 1976 (Thomas, J., dissenting).

${ }^{295}$ Ibid., 1965.

${ }^{296}$ Ibid., 1975 (Thomas, J., dissenting).

${ }^{297}$ See, e.g., http://www.cdc.gov/flu/weekly/regions2007-

2008/datafinal/senregallregion07-08.htm. 
${ }^{298}$ Saeed Shah, “CIA Organised Fake Vaccination Drive to Get Osama bin Laden’s family DNA,” July 11, 2011, Guardian, UK, available at http://www.guardian.co.uk/world/2011/jul/11/cia-fake-vaccinations-osama-bin-ladens-dna; CNN World Report, "CIA Organized Vaccination Drive for DNA from bin Laden Home,” July 12, 2001, available at http://articles.cnn.com/2011-07-12/world/pakistan.bin.laden.dna_1_bin-ladenfamily-members-laden-dna-vaccination?_s=PM:WORLD; Grace Wyler, "Pakistan Arrests Doctor for Running CIA Vaccination Drive to Get Bin Laden's DNA,” Business Insider, July 11, 2001, available at http://www.businessinsider.com/pakistan-arrests-doctor-for-running-ciavaccination-drive-to-get-bin-ladens-dna-2011-7; Nick Allen, "CIA Set up Fake Vaccination Programme to Capture Osama bin Laden's DNA," Telegraph, August 29, 2011, available at http:/www.telegraph.co.uk/news/worldnews/al-qaeda/8631420/CIA-set-up-fake-vaccinationprogramme-to-capture-Osama-bin-Ladens-DNA.html; Mark Mazzetti, "Vaccination Ruse Used in Pursuit of Bin Laden," New York Times, July 11, 2011, available at http://www.nytimes.com/2011/07/12/world/asia/12dna.html.

${ }^{299}$ S. Reardon, "Decrying CIA Vaccination Sham, Health Workers Brace for Backlash," Science 333, no. 6041 (July 22, 2011): 395, available at http://www.sciencemag.org/content/333/6041/395.citation.

${ }^{300}$ See, e.g., Richard E. Hoffman and Jane E. Norton, “Lessons Learned from a FullScale Bioterrorism Exercise," Emerging Infectious Diseases 6, no. 652 (2000).

${ }^{301}$ See discussion in Donohue, "Biodefense and Constitutional Constraints," supra note 59. 